\title{
An Exploration of Food Insecurity, Poverty, Livelihood and Local Food Potentials in Kulon Progo Regency, Indonesia
}

\author{
Dodi Widiyanto \\ Graduate School of Environmental Studies, Nagoya University, Furo-cho, Chikusa-ku, Nagoya, \\ 464-8601, Japan. \\ The Faculty of Geography, Universitas Gadjah Mada, Jl. Kaliurang Km. 5 Bulaksumur, Sleman, \\ Yogyakarta 55281, Indonesia. \\ Corresponding author (e-mail: dodi.widiyanto@ugm.ac.id)
}

Received: 28 February 2018 / Accepted: 26 May 2018 / Published: 07 June 2018

\begin{abstract}
Kulon Progo has been struggled to cope with the issues of poverty and food insecurity. The provincial and local governments pay a lot of attention to tackling these deprivation problems. The BKPP DIY developed a composite index which concluded that poverty is the primary cause of the deprivation. Therefore, this paper aims to explore the rural deprivation in Kulon Progo by assessing its aspects including poverty, food insecurity conditions, livelihoods, and local food potentials. Several methods, including typology, livelihood calculation, and resource possibility mapping are introduced for the preliminary analysis of this deprivation. The findings show that in Kulon Progo, (1) most of the deprived areas are located in the typology of upland region, (2) based on its of five assets, in general, the livelihood condition in Kulon Progo needs an improvement on financial, natural, and physical capitals, and (3) presenting the local food clusters based on its local food plantation area and production, so that these findings could give alternatives for the decision makers to develop the rural (deprived) areas.
\end{abstract}

Keywords: food insecurity village, poverty, livelihood, local food potentials.

\begin{abstract}
Abstrak. Kabupaten Kulon Progo menghadapi permasalahan kemiskinan dan kerawanan pangan. Berbagai upaya untuk mengatasi dua permasalahan tersebut terus dilakukan oleh pemerintah provinsi maupun kabupaten. Salah satu upaya yang dilakukan adalah dengan menyusun indeks komposit desa rawan pangan. Kemiskinan diyakini sebagai penyebab utama masalah tersebut. Sehingga paper ini bertujuan untuk mengesplorasi permasalahan tersebut dengan cara mendalami fenomena kemiskinan, kerawanan pangan, penghidupan, dan potensi pangan lokal yang tersedia di Kabupaten Kulon Progo. Berbagai metode digunakan untuk menjawab permasalahan tersebut, antara lain dengan menyusun tipologi, penghitungan potensi penghidupan, dan memetakan potensi sumberdaya sebagai upaya untuk identifikasi awal berbagai permasalahan yang ada. Penelitian ini menemukan bahwa (1) sebagian besar desa rawan, baik rawan kemiskinan dan/atau rawan pangan berada di tipologi daerah atas, (2) menurut kajian penghidupan, dari lima aset penghidupan yang dianalisis, secara umum, Kabupaten Kulon Progo memerlukan perhatian khusus kepada modal finansial, alamiah, dan fisikal, (3) penyajian kluster potensi pangan lokal hasil identifikasi dari penelitian ini, diharapkan dapat ditindaklanjuti oleh pemerintah daerah dalam rangka mengatasi permasalahan kemiskinan dan kerawanan pangan.
\end{abstract}

Kata Kunci: desa rawan pangan, kemiskinan, penghidupan, potensi pangan lokal.

\section{Introduction}

Poverty and food insecurity are two interacting aspects that potentially disrupt the livelihood of people, especially in developing countries. A Nobel Prize-winning economist, Amartya Sen explains that the poverty can be defined in the two terms: "consumption" and "poverty line" (Sen, 1982, p. 9). Moreover, according to Sen (1982, p. 11), the poverty should be defined as "identification" and "aggregation" for explanation. The identification concept pays attention to the group of poor people, while the aggregation concept refers simply to a composite of what poverty is. Poverty is a never-ending complex issue, and so many scholars have been 
interested in discussing it. One notable aspect explains poverty as the concept of deprivation (Noble et al., 2006; Sen, 1982). According to Noble et al. (2006, p. 172), the poverty is related to the conditions that people cannot fulfil financial demands, while the deprivation is caused by other factors such as "lack of resources". A previous research by Pereira et al. (2014, p. 340) argues that well-managed "household's assets" are needed to enhance the food security. Similarly, concerning assets rooted in the livelihood literature, Ellis (2000, p. 10) define "a livelihood comprises the assets (natural, physical, human, financial and social capital), the activities, and the access to these (mediated by institutions and social relations) that together determine the living gained by the individual or household".

Indonesia is one of developing countries which is some of its areas are prone to poverty and food insecurity, especially in Yogyakarta Special Province. According to various digital and paper-based mass-media reports, until 2016 twenty villages in Yogyakarta Special Province have been recorded as the category of severe on food insecurity (Bisnis.com, 2016; Sindo, 2016; Solopos.com, 2016). Kulon Progo, as part of Yogyakarta Special Province, faces the most severe condition of food insecurity compared to other regencies within this area in 2015. The Yogyakarta Special Province for Food Security Agency and Extension (Badan Ketahanan Pangan dan Penyuluhan/BKPP DIY) officially published the classification of food insecurity villages. For measuring food insecurity, the BKPP DIY uses three indicators for each village: local food production, purchasing power parity, and access to food (Bisnis.com, 2016). Furthermore, a food insecurity village, characterised by these three aspects including declining in purchasing power, lack access to gain food, and low production of local food (Bisnis.com, 2016).

Food insecurity is easily defined as the opposite concept of food security. Food insecurity cannot be separated from the matters of poverty, livelihood, and resources (Borch \& Kjærnes, 2016; Carlson et al., 1999; Eroğlu, 2013; Frongillo, 1999; Hadley \& Crooks, 2012; Mooney \& Hunt, 2009; Rose, 1999; Tomlinson, 2013). It potentially leads to hunger and malnutrition if not well-managed
(Borch \& Kjærnes, 2016; Carlson et al., 1999; Frongillo, 1999; Rose, 1999). To tackle the hunger problem due to food insecurity, Mooney \& Hunt (2009, p. 477) suggest improving the quantity side and point out the importance of "access" particularly on how poor people could attain food. Mooney \& Hunt's statement is supported by Pereira et al. (2014) who explain that for poor people the income limitation is an obstacle for accessing food.

Food insecurity emerges as a national issue in the Indonesian context. The Central Government has increasingly paid more attention to this issue and then stipulated the Law of Food (Law No. 18) in 2012. It was in 2005 when the Central Government published its first initiative policy document which paid attention to food insecurity issue. The Central Government, which was represented by Dewan Ketahanan Pangan worked altogether with World Food Programme to produce its first policy document, Food Insecurity Map (DKP et al., 2009). This program continued from 2009 to 2015 when the Central Government published Food Security and Vulnerability Atlas or FSVA (DKP et al., 2009; DKP et al., 2015). The maps help the decision makers and users to identify the food insecurity regions by the composite index (DKP et al., 2009).

Due to its problem of the statistical unit, the FSVA document only present the information at the national, provincial, and Regency/ municipality levels. There is no information in this document if stakeholders or users are willing to seek for analysis at the village level. Indeed, for example, there are two studies, which explain food insecurity conditions in the rural area (Hapsari \& Rudiarto, 2017; Subejo et al., 2017). These studies explain accurately on how the importance to adopt the FSVA method as a mean for the decision makers to alleviate food insecurity. It also gives some reliable answer for village-level under-researched gaps by other data as a complementary, which has not been demonstrated by previous FSVA studies. The provincial or regency government also gives such information. For example, in Yogyakarta Special Province, the BKPP DIY regularly publishes an annual report that contains information of food insecurity villages. 


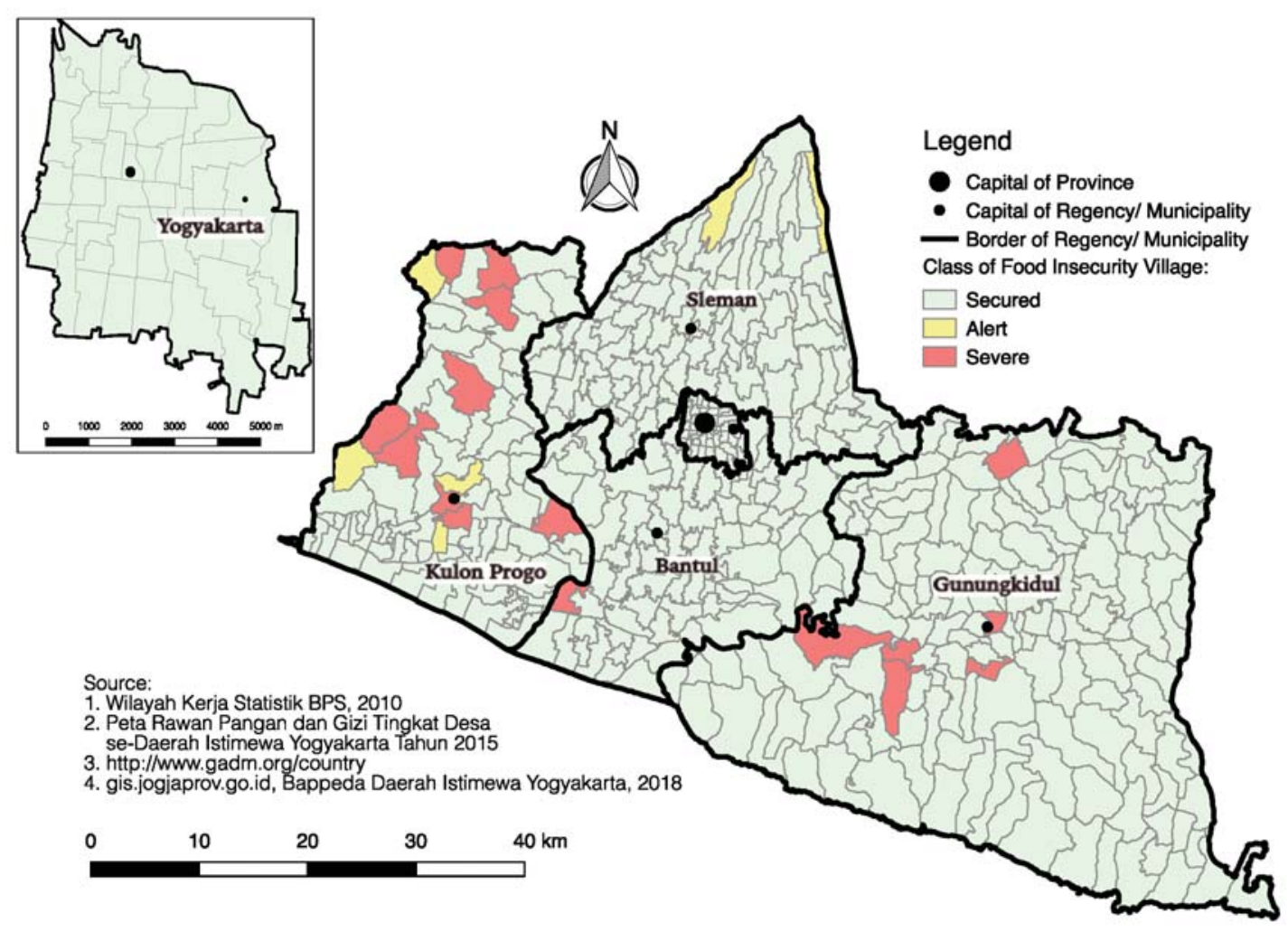

Figure 1. Food Insecurity Villages of Yogyakarta Special Province, 2015.

In addition, several previous studies on livelihood have been conducted in the Yogyakarta Special Province context (Baiquni, 2008; Rijanta, 2008; Sutanto, 2008; Widyatmoko, 2008; Gunardo, 2004), enriched with some studies from the other developing countries (Kristjanson et al., 2005; Magombeyi et al., 2016). The studies in Yogyakarta Special Province explain how rural households have coped with Indonesia's financial crisis in 1998. On the other hand, different perspectives of livelihood are offered in the spatial context rather than in the household or individual context. Some previous articles discuss livelihood in the regional settings. For example, a study of Kenya's experience offers how to map livelihood at a sub-district level (Kristjanson et al., 2005). Another survey in Africa presents an effort on how to conduct a spatial analysis by mapping four components: food insecurity, poverty, livelihood and water resources (Magombeyi et al., 2016). However, the study of poverty, food insecurity, livelihood and local food potentials in spatial perspective is limited.
This article presents the discussion for food insecurity village from a different dimension to address the limitations by analysing these published village data at the regional level and adopting the concepts of local food centres and local food crops introduced in the previous study (Subejo et al., 2017). Therefore, the primary aim of this paper is to present a description of the geographies of rural deprivation in Kulon Progo Regency. Spatial analyses were used to map the poverty, food insecurity, livelihood and local food potentials in this area.

\section{Research Method \\ 2.1. Research Design}

The research is taken place in Kulon Progo Regency (Figure 1) that locates in the west part of Yogyakarta Special Province, Indonesia, and which is divided into 12 sub-districts (Kecamatan) and subdivided into 88 villages (Desa). According to the BPS Kulon Progo (BPS, 2008), Kulon Progo Regency is divided into three parts from north to south. The north part consists of the sub-districts of Girimulyo, 
Nanggulan, Kalibawang, and Samigaluh. Sub-districts as Sentolo, Pengasih, and Kokap locate in the middle section. Temon, Wates, Panjatan, Galur, and Lendah are in the south part. These geographical parts have their specific characteristics: upland areas in the north region, transitional and hilly areas in the middle section, and lowland areas in the south part, respectively (BPS, 2008). This paper uses three geographical terminologies: upland, transitional, and lowland regions to explain the geographic profiles.

This paper employs an exploratory research design presented in Figure 2. This flowchart shows the process that is conducted in this paper starting from defining research questions, then reviewing previous works of literature, next presenting the research questions. It is followed by offering its research methods and results. The next step is a discussion, and finally, this paper is closed with conclusions.

\subsection{Data Used and Data Processing}

This research utilises secondary data which are published by the government and non-government institutions (BKPP DIY and SMERU, respectively). In detail, the data concerning the food insecurity and the local food potential are derived from the BKPP DIY (BKPP, 2015), while the operational definition of poverty and livelihood comes from SMERU (SMERU, 2014). In particular, this research analyses 1) food insecurity; 2) the number of poor people based on the national poverty line; 3) livelihoods with five asset components; and 4) local food potentials (Table 1, the details scoring and weighting is provided in Appendix 1).

Firstly, the data on poverty and local food production are processed by Microsoft Excel and QGIS 2.18 software. A classification gives a meaning for the values or constructed index (Noble et al., 2006). Natural Breaks (Jenks) method that leads to specific/classification of the village poverty levels and local food potentials is chosen for this research. According to Brewer and Pickle (2002, p. 663), Natural Breaks is selected due to its ability "to minimise variation within classes". Helped by QGIS software, the calculation leads to a threecategory classification: high, medium, and low rating. Indonesia's Law of Food (Law No. 18) is used to identify the production of the local food. Based on this, local food is defined as food that is consumed by local people based on the local production potentials and the local wisdom or indigenous knowledge. For the local food production and potential, this paper focusses 10 kinds of tuber: cassava (ubi kayu), sweet potato (ubi jalar), edible canna (ganyong), arrowroot (garut), prasina (gadung), birch rim yam (gembili), pumpkin (labu), tuber (uwi), breadfruit (sukun), and lastly elephant's foot (suweg).

The classification of food insecurity villages has been conducted by the BKPP DIY (BKPP, 2015). This classification is resulted from developing the food insecurity index, graded by the points on food availability, access and utilisation. To measure the food availability, the BKPP uses three-year average production outputs of rice, maize, cassava, and sweet potato. The reason for the BKPP DIY to choose these crops is based on the argument that the primary source of human energy comes from cereals and tubers (BKPP, 2015). The BKPP DIY (2015) states that "more than $50 \%$ of food consumption in Indonesia is from grains on the calorie basis" (translated by the author from Bahasa). Further, to construct the access parameter, the BKPP DIY employs PreWelfare Households (Keluarga Pra-Sejahtera) and Welfare Households level 1 (Sejahtera I) which are supported by the time-series data of Monthly-price, Farmers' Terms of Trade Indices (Nilai Tukar Petani), and Human Development Index (Indeks Pembangunan Manusia). Lastly, the food utilisation is explained by the level of children-underfive underweight (prevalensi gizi kurang pada balita). The three measures are combined to construct the composite index by the BKPP DIY. Therefore, it is supported by previous researchers on deprivation suggestion, that the best way to measure deprivation is to use by using a composite index (Messer et al., 2006; Noble et al., 2006). 


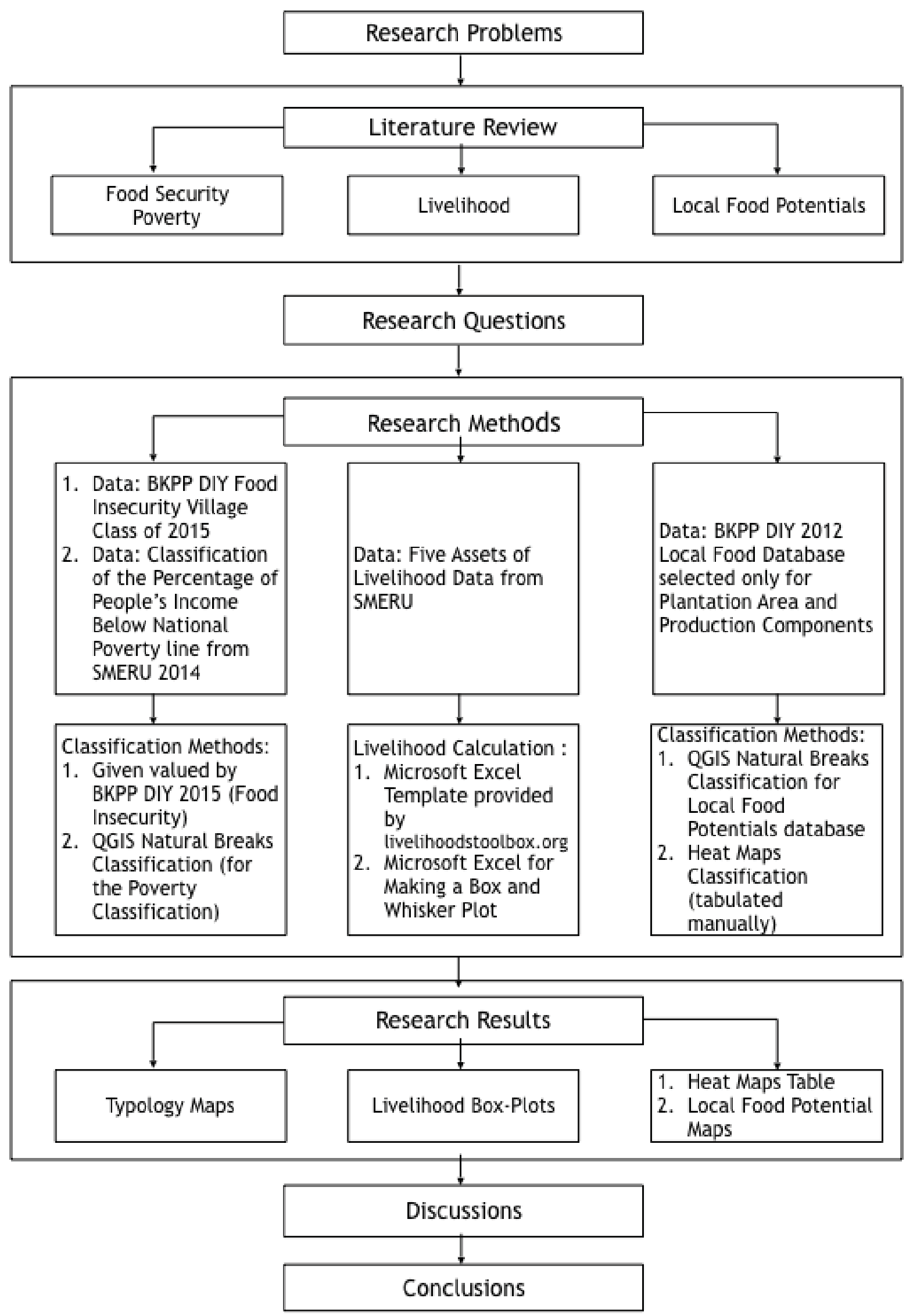

Figure 2. Research Design Flow Chart. 
Table. 1. Poverty, Food Insecurity, Local Food and Livelihood Data.

\begin{tabular}{|c|c|c|c|}
\hline No & Component & Indicators & Data Source \\
\hline 1 & Poverty & $\begin{array}{l}\text { The number of people below the national } \\
\text { poverty line }\end{array}$ & $\underline{\text { SMERU, } 2014}$ \\
\hline 2 & Food Insecurity & Food Insecurity Villages Category (Class) & $\underline{\text { BKPP, } 2015}$ \\
\hline 3 & Livelihood & $\begin{array}{l}\text { 1. Natural Capital } \\
\text { 2. Physical Capital } \\
\text { 3. Human Capital } \\
\text { 4. Financial Capital } \\
\text { 5. Social Capital } \\
\text { Notes: Detail of these indicators present in } \\
\text { appendix } 1\end{array}$ & $\underline{\text { SMERU, } 2014}$ \\
\hline 4 & Local Food & $\begin{array}{l}\text { Plantation Area and Production of Ten of } \\
\text { Local Food Crops }\end{array}$ & $\underline{\mathrm{BKPP}, 2015}$ \\
\hline
\end{tabular}

In particular, following the suggestion from previous researchers then this paper offers a combination approach for constructing the deprivation typology (Glaeser, 2016; Messer et al., 2006; Noble et al., 2006). Combination of poverty and food security construction is also suggested by other scholars (Magombeyi et al., 2016), with their 'tandem' terminology. The poverty component is derived from the number of poor people below the national poverty line, containing three classes: high, medium, and low. In another word, the food insecurity component includes three classes of the food insecurity village: severe, alert, and secure, derived from the BKPP DIY report (2015). The BKPP DIY's typology of food insecurity villages was adopted to categorise the poverty: 'severe' to 'high', 'alert' to 'medium', and 'secure' to 'low' categories. Finally, LISA approach was used to construct a 'new typology' (Anselin, 1995). Anselin's idea presents a categorical approach by providing a quadrant analysis of low-low, low-high, highlow, and high-high categorisation. However, this paper needs to present nine cells that are consisted of three classes for each component. Therefore, the 'new typology' was modified into low-low, low-medium, medium-low, mediummedium, high-low, high-medium, low-medium, medium-high, and high-high. Scenario planning discipline employs this nine cells classification or $3 \times 3$ matrix (Ringland, 1998).

The process of livelihood counting and graphing is supported by the MS-Excel macrotoolkit Livelihoods Toolbox (beta), which is provided by the International Federation of Red Cross and Red Crescent, available at http:// www.livelihoodstoolbox.org. Following the guideline of this tool, it is essential to use the values for inputting that is weighted on raw scores based on the community or household perspectives. However, in this paper, the weight for eachindicator is given by theresearcher (please see notes in Appendix 1 for the explanation), considering the importance of every index for the regional settings. Finally, the box and whisker plot were drawn by using Microsoft Excel based on Rowell's tutorial (Rowell, 2012).

\section{Results and Discussion}

\subsection{Village Typology of Severe Conditions}

The typology of all the villages in Kulon Progo is constructed from the two dimensions of poverty and food insecurity, each of which includes three categories of 'low', 'medium', and 'high'. The calculation leads to 9 classifications (Figure 3 and Table 2). There are nine typologies and then be categorised into two distinct groups: un-severe and severe groups. Furthermore, this distinction has four categories: 1) un-severe; 2) severe on poverty; 3) severe on food, and 4) critical on both (poverty and food). In general, most of the villages in Kulon Progo are un-severe villages (68 villages). The rest of communities, 20 of 88 villages, are severe villages (Table 3 ). Eleven villages have a problem of poverty. Meanwhile, seven villages have to struggle with food insecurity. Finally, two communities are facing both issues: poverty and food insecurity. 
Legend

- Border of Regency

Typology of Poverty and Food Insecurity Village:

$\square$ Low - Low

Low - Medium

Low - High

Medium - Low

Medium - Medium

Medium - High

High - Low

High - Medium

High - High

Source:

1. Wilayah Kerja Statistik BPS, 2010

. Data Peta Kemiskinan dan Penghidupan Indonesia

2014, SMERU, accessed from povertymap.smeru.or.id

3. Peta Rawan Pangan dan Gizi Tingkat Desa

se-Daerah Istimewa Yogyakarta Tahun 2015,

Satuan Kerja Badan Ketahanan Pangan dan

Penyuluhan Propinsi DIY
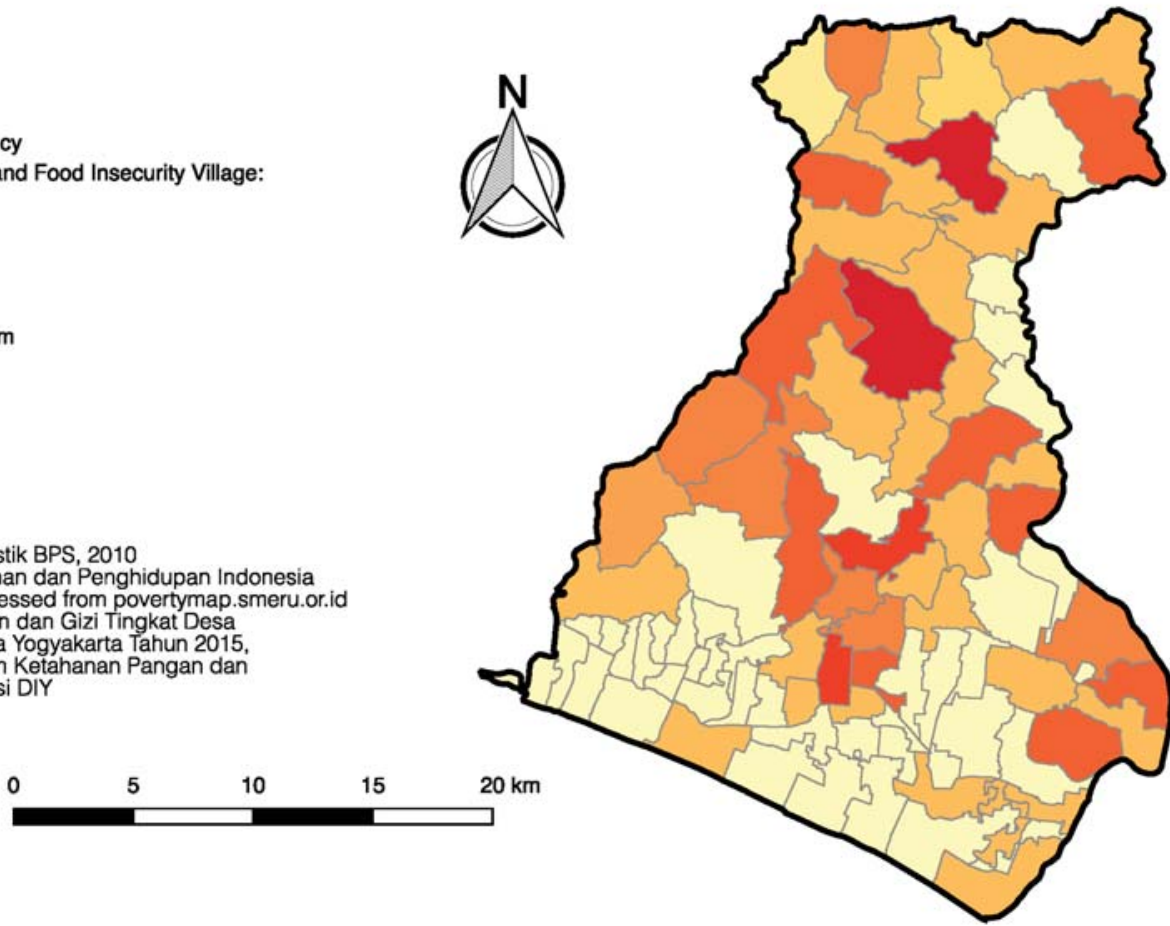

Figure 3. Typological Map of Poverty and Food Insecurity Villages in Kulon Progo.

Table 2. The number of village Typologies in Kulon Progo.

\begin{tabular}{llcl}
\hline No & $\begin{array}{c}\text { Typology } \\
\text { (Poverty and Food Insecurity } \\
\text { Villages) }\end{array}$ & $\begin{array}{c}\text { Number of } \\
\text { Villages }\end{array}$ & \multicolumn{1}{c}{ Category } \\
\hline 1 & Low-Low & 41 & Un-severe \\
2 & Low-Medium & 1 & Un-severe \\
3 & Medium-Low & 25 & Un-severe \\
4 & Medium-Medium & 1 & Un-severe \\
5 & High-Low & 9 & Severe on Poverty \\
6 & High-Medium & 2 & Severe on Poverty \\
7 & Low-High & 1 & Severe on Food \\
8 & Medium-High & 6 & $\begin{array}{l}\text { Severe on Food } \\
\text { Critical on Both (Poverty } \\
9\end{array}$ \\
High-High & 2 & and Food) \\
\hline
\end{tabular}


Table 3. Villages in severe condition in Kulon Progo.

\begin{tabular}{|c|c|c|c|c|}
\hline No. & Village Name & Geographical Zones $\left(^{*}\right)$ & $\begin{array}{c}\text { Typology (Poverty } \\
\text { Figure and Food } \\
\text { Insecurity) }\end{array}$ & Category \\
\hline 1 & Gotakan & Lowland & High - Low & $\begin{array}{l}\text { Severe on } \\
\text { Poverty }\end{array}$ \\
\hline 2 & Sidorejo & Lowland & High - Low & $\begin{array}{l}\text { Severe on } \\
\text { Poverty }\end{array}$ \\
\hline 3 & Ngentakrejo & Lowland & High - Low & $\begin{array}{l}\text { Severe on } \\
\text { Poverty }\end{array}$ \\
\hline 4 & Sentolo & Transitional & High - Low & $\begin{array}{l}\text { Severe on } \\
\text { Poverty }\end{array}$ \\
\hline 5 & Karangsari & Transitional & High - Low & $\begin{array}{l}\text { Severe on } \\
\text { Poverty }\end{array}$ \\
\hline 6 & Jatimulyo & Upland & High - Low & $\begin{array}{l}\text { Severe on } \\
\text { Poverty }\end{array}$ \\
\hline 7 & Donomulyo & Upland & High - Low & $\begin{array}{l}\text { Severe on } \\
\text { Poverty }\end{array}$ \\
\hline 8 & Banjarharjo & Upland & High - Low & $\begin{array}{l}\text { Severe on } \\
\text { Poverty }\end{array}$ \\
\hline 9 & Kebonharjo & Upland & High - Low & $\begin{array}{l}\text { Severe on } \\
\text { Poverty }\end{array}$ \\
\hline 10 & Bendungan & Lowland & High - Medium & $\begin{array}{l}\text { Severe on } \\
\text { Poverty }\end{array}$ \\
\hline 11 & Pengasih & Transitional & High - Medium & $\begin{array}{l}\text { Severe on } \\
\text { Poverty }\end{array}$ \\
\hline 12 & Sidoharjo & Upland & Low - High & Severe on Food \\
\hline 13 & Giripeni & Lowland & Medium-High & Severe on Food \\
\hline 14 & Wates & Lowland & Medium-High & Severe on Food \\
\hline 15 & Tuksono & Transitional & Medium-High & Severe on Food \\
\hline 16 & Hargowilis & Upland & Medium-High & Severe on Food \\
\hline 17 & Hargotirto & Upland & Medium-High & Severe on Food \\
\hline 18 & Ngargosari & Upland & Medium-High & Severe on Food \\
\hline 19 & Giripurwo & Upland & High - High & $\begin{array}{l}\text { Critical on Both } \\
\text { Poverty and } \\
\text { Food }\end{array}$ \\
\hline 20 & Purwoharjo & Upland & High - High & $\begin{array}{l}\text { Critical on Both } \\
\text { Poverty and } \\
\text { Food }\end{array}$ \\
\hline
\end{tabular}

$\left(^{*}\right)$ Geographical Zones are categorised by Kulon Progo BPS (2008).

The severe categories of the typology are then related to the geographical zones (Table 3). Firstly, the evidence shows that the poverty-severe villages are located in all geographical zones: upland, transitional, and lowland area. Secondly, the severe food insecurity communities are found mostly in the upland area. Thirdly, two villages that are embedded in both severe conditions: poverty and food, are located in the upland area. In short, based on this explanation, most of the severe villages (poverty, food, and both categories) are generally located in the upland area. 

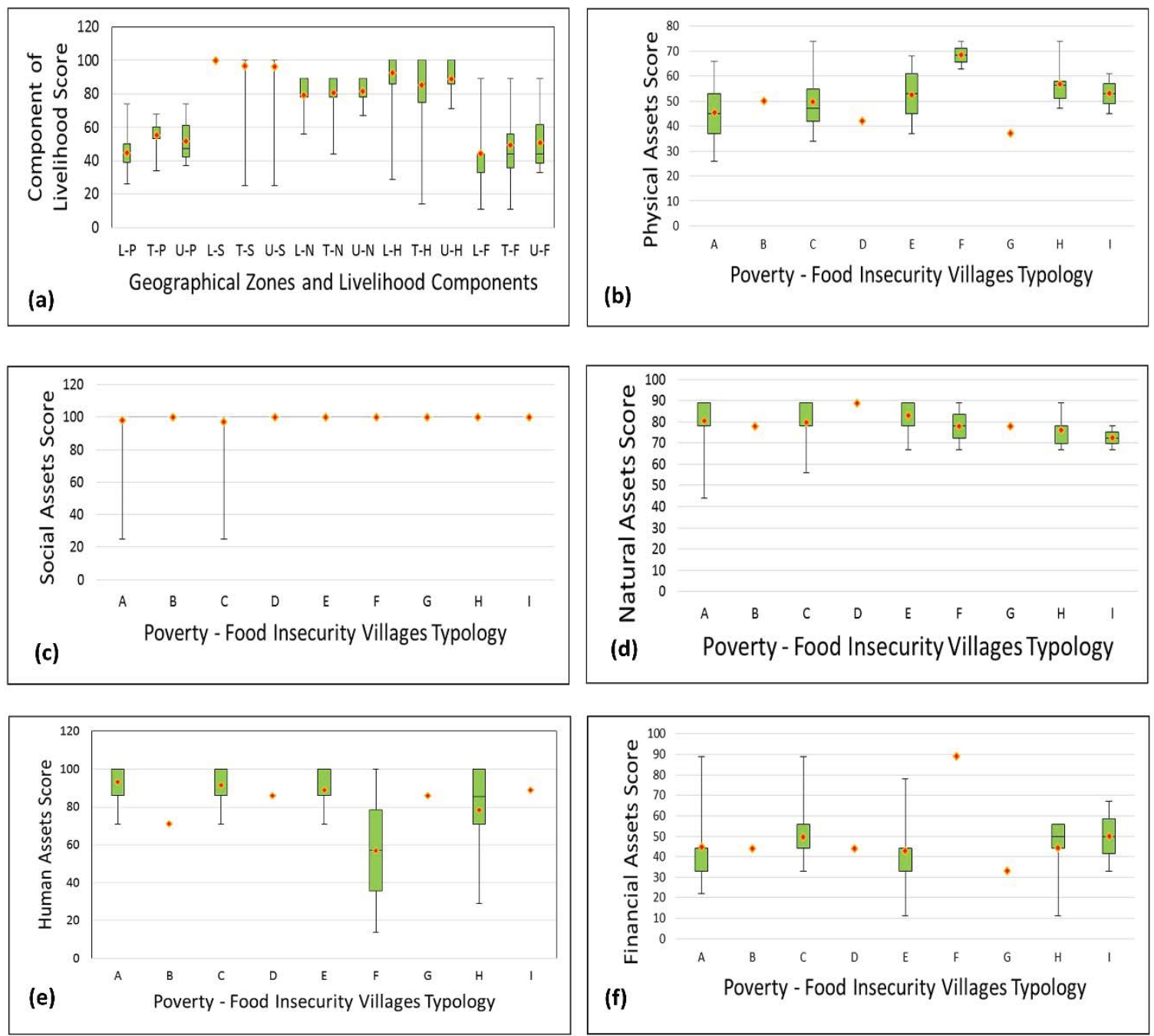

Figure 4. Characteristics of Capital Assets of Livelihoods in Kulon Progo. Note for Figure 4a: L-P: LowlandPhysical Assets; T-P: Transitional-Physical Assets; U-P: Upland-Physical Assets; L-S: Lowland-Social Assets; T-S: Transitional-Social Assets; U-S: Upland-Social Assets; L-N: Lowland-Natural Assets; T-N: Transitional-Natural Assets; U-N: Upland-Natural Assets; L-H: Lowland-Human Assets; T-H: Transitional-Human Assets; U-H: Upland-Human Assets; L-F: Lowland-Financial Assets; T-F: Transitional-Financial Assets; U-F: Upland-Financial Assets. Note for Figure 4b - 4f: A:Low-Low, B: Low-Medium, C: Low-High, D: Medium-Low, E: Medium-Medium, F: Medium-High, G: High-Low, H: High-Medium, I: High-High.

\subsection{Capital Assets of Livelihoods}

This part presents the five capital assets of livelihood based on their geographical variations related to the proposed typology (Figure 4). The figure shows that the social asset shows the highest value compared to others, followed by the human asset. Next, the natural asset is on the third rank, followed by the physical assets and lastly, the financial asset stand for the last position. Meanwhile, geographically, a comparison is given to the lowland, the transitional, and the upland regions. There is an unequal distribution of the physical, human, and financial assets. A significant gap of uneven distribution is found in the upland area for the physical asset. Meanwhile, in the transitional region, there are only a few gaps. Lastly, the financial asset tends to be a problem in the transitional and the upland areas because of its unequal distribution.

The geographic difference of livelihood assets is shown in Figure 4a. In this figure, there is an evident difference in the values among 
five livelihood assets in Kulon Progo (Figure 4a). Moreover, the physical livelihood asset in Kulon Progo shows various values according to the typologies (Figure $4 \mathrm{~b}$ ). In general, there are no differences among communities that are grouped into un-severe areas: low-low, low-medium, medium-low, and mediummedium, an unequal distribution being found only in the medium-medium typology. For the second group of poverty typology: highlow and high-medium, there seem no uneven distributions. Meanwhile, for the third group, the food insecurity villages, there is an unequal distribution. For the last group is severe group of both typologies: high-high. For this severe group, there is no difference between the villages. Furthermore, for the social livelihood, there are no differences among the nine typologies (Figure 4c). For the un-severe group, nevertheless, it is found that there is a significant gap for the values of two types of regions: lowlow and medium-low. While the values of the natural livelihood asset tend to decrease following the severity of poverty and food insecurity (Figure 4d). In general, the natural asset seems to affect the critical groups. It is more likely to change the rural food insecurity villages than the poverty group. In Kulon Progo, relatively no problem can be pointed on the condition of the human livelihood asset, except for the poverty and food un-secured village group: high-medium and medium-high (Figure 4e). There are some significant values in these types of community. In short, the human capital affects the poverty group. Last, the financial capital asset has a lower average value, an interval range extending around 30-60 in average (Figure 4f). In general, the number of financial institutions are relatively limited, it leads to unequal distribution of the financial asset and less availability of these financial services.

\subsection{Local Food Production and Potential}

To answer the question of which regions have local food potentials is given in this part. In this paper, the local food potential is operationally defined as production amount and plantation areas of local food crops. The argument that is offered for the reason is (1) the output has relations to how every community produces a variety of local food crops, and (2) the plantation area reflects the future availability of local food crops, mainly for the variety of tubers that need more extended time for being collected. It is known that more than six months are necessary to harvest some tubers.

This part tries to identify spatial specialisation and concentration of local food production at the regional level. As seen in Figure 5, Kulon Progo potentially has various local food crops (see Appendix 2). The distribution of these local food crops is varied based on the geographical division of labour. In general, the high potential of local food-planting villages is seen in every geographic region. However, the areas of the plantation are varied. Some communities have large plantation areas compare to others. For example, in the upland area, the high potential of local food crops regarding plantation areas mainly concentrate in the west part. In this cluster, potentially crops such as sweet potato, edible canna and elephant's foot have been planted. In the middle or transitional zone, the concentration of highly planted food crops is also seen in the western part. Several varieties of local food crops potentially are found in this cluster, including cassava and elephant's foot. Finally, in the lowland region, the concentration of local food crops is mostly found in two clumps: middle and east parts. In the part cluster, the highly potential local food crops are sweet potato, edible canna, and pumpkin. Meanwhile, in the eastern group, the potentially main product are cassava, arrowroot, prasina, birch rim yam, pumpkin, tuber, breadfruit and elephant's foot. In short, in the future starting from the year of harvesting, these clusters have a prospect for providing local food products in Kulon Progo. 


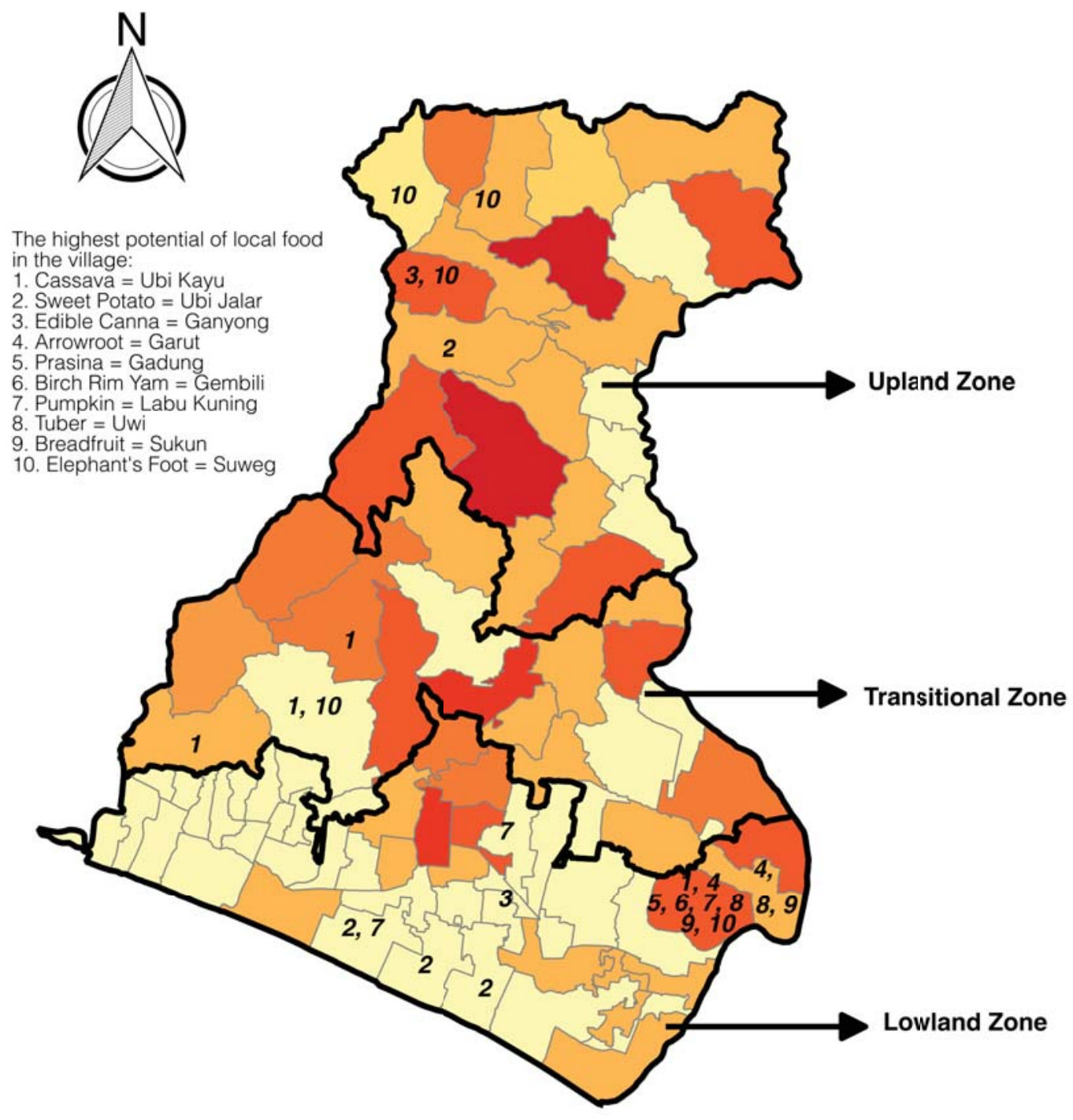

\section{Legend}

- Geographical Zone Boundary:

Typology of Poverty and Food Insecurity Village:

$$
\begin{aligned}
& \text { Low - Low } \\
& \text { Low - Medium } \\
& \text { Low - High } \\
& \text { Medium - Low } \\
& \text { Medium - Medium } \\
& \text { Medium - High } \\
& \text { High - Low } \\
& \text { High - Medium } \\
& \text { High - High }
\end{aligned}
$$

Figure 5. Local Food Plantation Area based on its Geographical Variations and Typology.

\section{Source:}

1. Wilayah Kerja Statistik, BPS, 2010

2. Data Peta Kemiskinan dan Penghidupan Indonesia 2014, SMERU: accessed from povertymap.smeru.or.id

3. Peta Rawan Pangan dan Gizi Tingkat Desa se-Daerah Istimewa Yogyakarta Tahun 2015 Satuan Kerja Badan Ke:ahanan Pangan dan Penyuluhan Propinsi DIY

4. Researcher calculation from Laporan Kegiatan Peryusunan Database Pangan Lokal 2012, Badan Ketahanan Pangan dan Penyuluhan Daerah Istimewa Yogyakarta

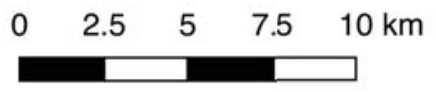




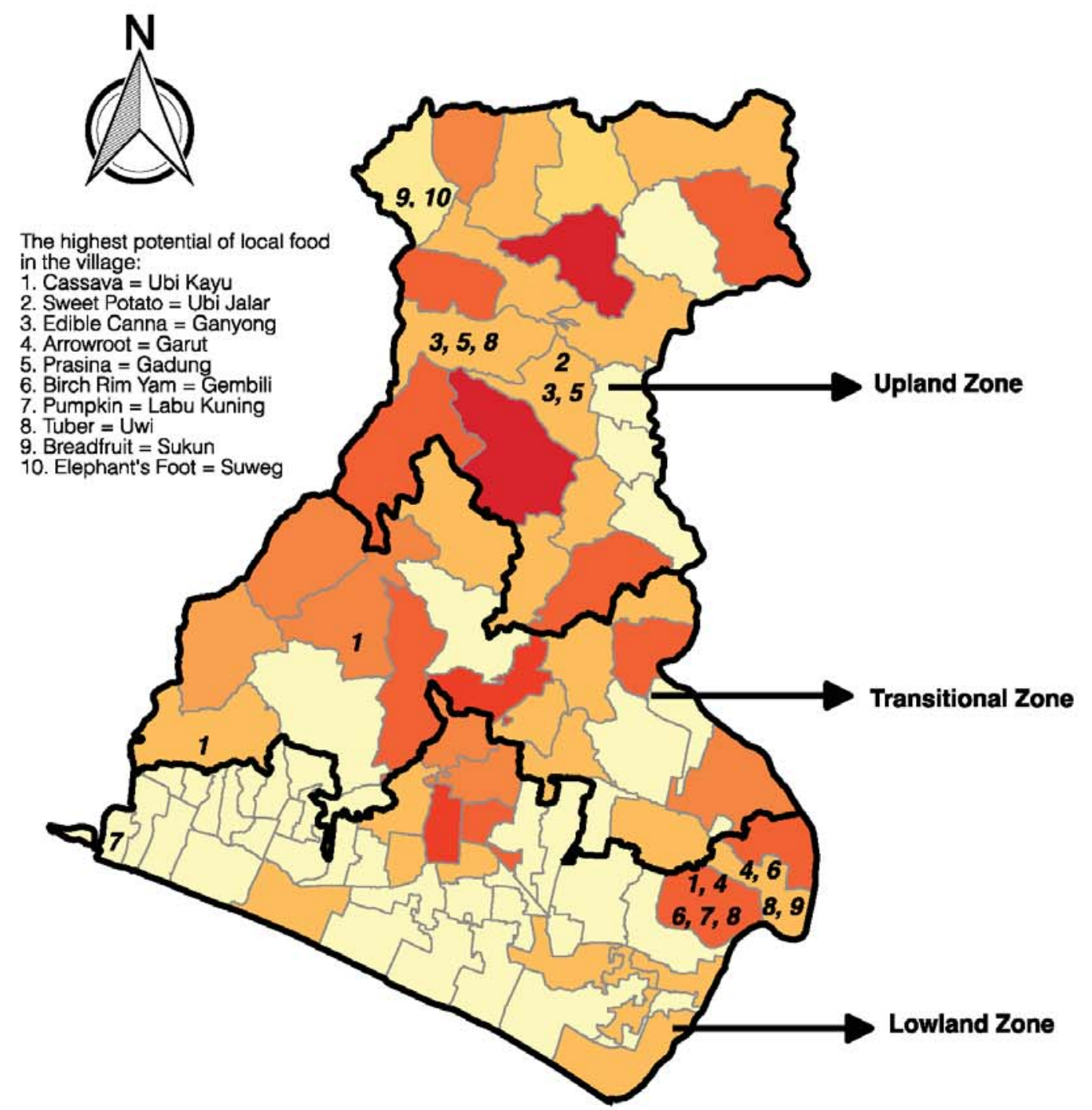

Legend

Geographical Zone Boundary:

Typology of Poverty and Food Insecurity Village:

Low - Low

Low - Medium

Low - High

Medium - Low

Medium - Medium

Medium - High

High - Low

High - Medium

High - High
Source:

1. Wilayah Kerja Statistik, BPS, 2010

2. Data Peta Kemiskinan dan Penghidupan Indonesia 2014, SMERU: accessed from povertymap.smeru.or.id

3. Peta Rawan Pangan dan Gizi Tingkat Desa se-Daerah Istimewa Yogyakarta Tahun 2015 Satuan Kerja Badan Ketahanan Pangan dan Penyuluhan Propinsi DIY

4. Researcher calculation from Laporan Kegiatan Penyusunan Database Pangan Lokal 2012, Badan Ketahanan Pangan dan Penyuluhan Daerah Istimewa Yogyakarta

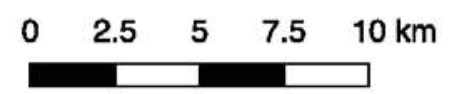

Figure 6. Local Food Production based on its Geographical Variations and Typology. 


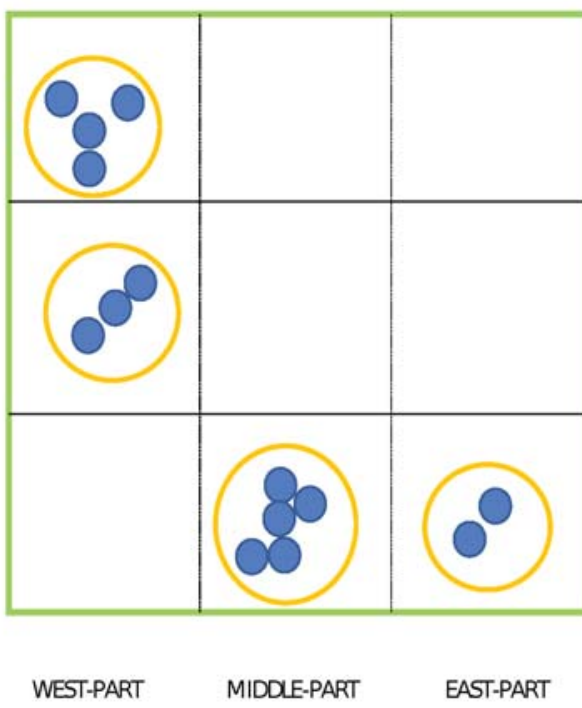

A. IUUSTRATION OF HIGHUY DISTRIBUTEDOF LOCALFOOD PLANTATION AREA

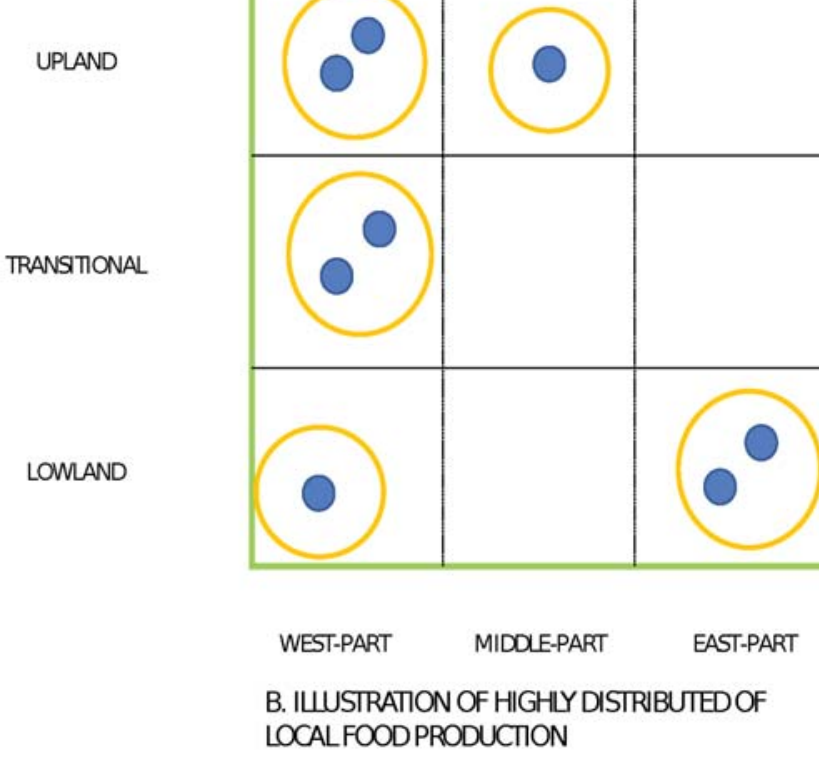

Figure 7. Visualisation of Local Food Potentials Clusters in Kulon Progo.

It is merely to be said that production reflects a regional capacity. The classification of local food crops production can be identified in Figure 6 (see Appendix 3 for detail). The high output of local food can be found in each of the three geographical regions. In the upland area, for instance, the highly producing villages of local food crops are located in the west and the middle parts. In these two clusters such crops as edible canna, prasina, breadfruit and elephant's foot are much produced in the western group, while the middle cluster has produced cassava, sweet potato, edible canna, and prasina. In the transitional region of Kulon Progo, cassava is the leading local food crop that is much produced in the western part. Finally, there are two production clusters of local food in the lowland region of Kulon Progo, namely western and east cluster. In the west group, there is the only pumpkin that is mainly produced. Meanwhile, in the eastern part, various local food crops are much provided, including cassava, arrowroot, birch rim yam, tuber, and breadfruit.

The illustration of the spatial concentration of local food potential (Figure 7) is derived from the local food maps (Figure 5 and 6). I reconstruct the local food maps by dividing each geographical zone into three imaginaries boundaries: west-part, middle-part, and eastpart. As seen in Figure 7A, four villages with the highest local plantation area locate in the upland area. There are three villages in the transitional zone with the high local food potential. For the lowland area, the concentration of local food plantation is found in the middle part and the east part consisting of five and two villages respectively. Figure $7 \mathrm{~B}$ shows the concentration of local food potentials based on the production dimension. The highest local food production is found in three cells of the western parts across all the geographical zones. There are two villages in the upland zone, two villages in the transitional region, and one village in the lowland zone with their highest potential of local food production. In contrast, there is only a village with the highest local food production potential in the middle part of the upland cell. Finally, two communities have the highest local food production potential that fills in the east part of the lowland cell.

\subsection{Discussion}

The primary purpose of this paper is presenting an explanation of the spatial dimension of poverty, food insecurity, livelihood assets, and local food potentials looking at their regional differentiation, 
concentration, and specialisation. For the first discussion of this paper, a focus is placed on explaining the first research question: to what extent are rural communities deprived concerning the poverty and food insecurity conditions? Results of this research demonstrate that geographically, the deprived regions on poverty and food insecurity are located in the upland area.

Typologically, there are two groups of un-severe and severe villages in the conditions of poverty and food security. In general, the finding shows that most of the oppressed communities are located in the upland area (see Table 3). This finding is in line with Riggs's conclusion in his previous study in Laos (Rigg, 2006). He states that lack of needed infrastructures and unavailability of resources is the leading causes of poverty. In general, the upland areas, which is commonly far away from the local growth poles, potential face what Sen $(1982$, p. 1) calls as "structure of ownership". Explanation from Qudrat-I Elahi (2006, p. 543), the structure of ownership consists of four dimensions: "trade-based entitlement, production-based entitlement, own-labour entitlement, and inheritance and transfer entitlement". Later, Qudrat-I Elahi (2006, p. 543) discusses the four entitlement into two groups: "ownership possibilities" and "trade possibilities". Therefore, to improve the severe community condition, these two possibilities should be designed. On the one hand, providing ownership possibilities will reduce the food insecurity. On the other hand, the trade of possibilities will decrease the poverty. Several efforts are needed to reinforce the two possibilities, as developing and maintaining new infrastructures and to strengthen the community livelihood assets are several propose choices to reduce inequality between the un-severe and severe village typologies.

The second discussion relates to the second research question: whether are there any differences in the livelihood conditions according to the rural deprivation? Citing from Ellis's statement that livelihood is closely related to "poverty and rural development" (Ellis,
2000, p. 7), to support the rural development, this paper gives an additional explanation on the spatial patterns of livelihood assets and their relations to the future recommendation for the decision-makers. Additionally, considering the local context of Kulon Progo regency (see Figure 4), the physical, natural and financial livelihood assets in Kulon Progo tend to be more severe in the upland area.

A discussion of deprivation and livelihood hopefully will end up on the policy mainly related to the matter of local food. The argument is constructed from the evidence that almost all the villages potentially have local food productions. The previous research also supports this argument that the domestic product has a significant role in improving local people's welfare (Shackleton et al, 2008). Some options could be built from the previous research in Kutai Kartanegara (Subejo et al., 2017). There are at least two suggestions from their paper, first the importance to set up a regional food system, and the second suggestion is to maximise the local food availability. According to the results of this research, these two options could be adopted in the case of Kulon Progo by designing two choices, firstly planning a local food centre that is stipulated in the chapter IV article 12 and the $6^{\text {th }}$ subsection of Indonesian Law of Food and secondly persuading inhabitants of each village to start regularly consuming local food products in addition to daily rice consumption.

The last discussion concerns the previous research question: how are local food potentials related to the rural deprivation? In sum, a constructed typology is divided into four groups, namely un-severe, poverty severe, food severe, and both (poverty and food) severe. The finding shows that the deprived communities are mostly located in the upland areas. Livelihood conditions in Kulon Progo show that the financial, the physical, and the natural conditions need more concerns by all the stakeholders.

Local food potentials in Kulon Progo also encourage the decision makers to develop the local food centre and/or the local people to consumelocal food crops for daily consumption. 
As seen in Figure 7, the geographies in Kulon Progo have potential local food clusters to be developed, constructing the connection between these centres and the whole regions. This figure (Figure 7A and B) potentially could be used as the entry point to design a policy. By paying attention to the Figure 5, 6 and 7A and B, it can be seen that still there is such kind of "overlapping situation" where the most severe villages have no support by the highest local food potentials. In Figure 6, the village with the highest local food production, for example, locates in between of the most severe villages. Therefore the most severe villages need support on how to improve their infrastructure transportation connection and improve the social mechanism so these options will these villages "structure of ownership". So it will lead to the multiplier effect of the most severe villages.

The potential clusters (the nine cells of geographical zones and imaginary boundaries) could have a role to support the present local spirit of Kulon Progo such as Bela Beli Kulon Progo. The findings of this paper should be followedup by giving the scale of priorities, firstly to both critical poverty and food insecurity villages, then to the severe poverty or food insecurity villages. The identified cluster of local food production is supposed to contribute to reducing poverty and food insecurity conditions in the villages of Kulon Progo. Finally, the identified groups have options to be utilised for daily consumption and/or for sale of value-added products. The possibilities of daily consumption could reduce the food insecurity issue, on the one hand; the value-added products could tackle the poverty issue on the other.

\section{Conclusions}

To conclude, this paper shows the unequal geographical distribution of poverty and food insecurity based on the statistical data of the villages. The regional profiles of the rural deprivation in Kulon Progo are presented incorporating the distributions of the oppressive villages and their livelihood conditions. Finally, the local food potentials also are spatially shown in order to identify the concentration and specialisation of local food plantations or productions related to the policy recommendation.

This paper has several limitations that come from using relatively old data. So, the information in this paper could not express today's situations. For example, after six years since the significant data of this paper were published, there is transformation reflecting the regional performance of Kulon Progo regency and the villages. If there had been an updated publication regarding the local food potential database monitoring the regional production could show a better profile regarding the rural deprivation. Therefore, future issues for example related to the connection of local and regional food system should be explored in advance. This under-researched issues will give detail information on proposed local food centres and their relations in the more comprehensive geographical context. Another remaining question about how to encourage production of local food in non-central places, making ties among poverty, food insecurity, livelihood and local food potentials is exciting to be examined for the next research.

\section{Acknowledgements}

I would like to acknowledge the Indonesia Endowment Fund for Education (LPDP) Ministry of Finance, the Republic of Indonesia that is funding my research through BUDI LN Scholarship scheme under cooperation between RISTEKDIKTI and LPDP, my supervisors Professor Makoto Takahashi and Associate Professor Masaya Iga for valuable ideas, feedbacks and discussion so that I could improve and finished this paper. I would also like to say thanks to BKPP DIY and SMERU that provided and gave permission for me to use their data. I want to give credit to International Federation of Red Cross and Red Crescent (www.livelihoodstoolbox.org) for providing livelihood template that is very useful to process the livelihood data. I would like to say thank to GADM (https://gadm.org) for giving the electronic map for academic research purposes. I would like to thank two anonymous reviewers for the valuable comments, correction, and suggestions. 


\section{References}

Anselin, L. (1995). Local Indicators of Spatial Association - LISA. Geographical Analysis, 27(2), 93115. doi:10.1111/j.1538-4632.1995.tb00338.x.

Baiquni, M. (2008). The Economic and Ecological Crises and Their Impact on Livelihood Strategies of Rural Households in Yogyakarta. In M. J. Titus \& P. P. M. Burgers (Eds.), Rural Livelihoods, Resources and Coping with Crisis in Indonesia: A Comparative Study. Amsterdam: Amsterdam University Press.

Bisnis.com. (2016). RAWAN PANGAN: 20 Desa di Jogja Perlu Cadangan Logistik. Bisnis Indonesia. Retrieved from http://semarang.bisnis.com/read/20160216/1/85045/rawan-pangan-20desa-di-jogja-perlu-cadangan-logistik.

BKPP. (2015). Peta Rawan Pangan dan Gizi Tingkat Desa Se-Daerah Istimewa Yogyakarta Tahun 2015. Yogyakarta: Satuan Kerja Badan Ketahanan Pangan dan Penyuluhan (BKPP) Propinsi DIY.

Borch, A., \& Kjærnes, U. (2016). Food security and food insecurity in Europe: An analysis of the academic discourse (1975-2013). Appetite, 103, 137-147. doi:https://doi.org/10.1016/j. appet.2016.04.005

BPS. (2008). Kabupaten Kulon Progo Dalam Angka 2008. Kulon Progo: Badan Pusat Statistik Kabupaten Kulon Progo.

Brewer, C. A., \& Pickle, L. (2002). Evaluation of Methods for Classifying Epidemiological Data on Choropleth Maps in Series. Annals of the Association of American Geographers, 92(4), 662-681.

Carlson, S. J., Andrews, M. S., \& Bickel, G. W. (1999). Measuring Food Insecurity and Hunger in the United States: Development of a National Benchmark Measure and Prevalence Estimates. The Journal of Nutrition, 129(2), 510S-516S. doi:10.1093/jn/129.2.510S.

DKP, Pertanian, D., \& WFP. (2009). Peta Ketahanan Pangan dan Kerentanan Pangan Indonesia (A Food Security and Vulnerability Atlas of Indonesia) 2009. Retrieved from Jakarta: http:/ / documents. wfp.org/stellent/groups/public/documents/ena/wfp236710.pdf?iframe

DKP, Pertanian, D., \& WFP. (2015). Peta Ketahanan dan Kerentanan Pangan Indonesia 2015. Retrieved from Jakarta: http://documents.wfp.org/stellent/groups/public/documents/ena/ wfp276257.pdf?_ga=2.20858609.87287657.1516193730-1509766693.1516193730.

Ellis, F. (2000). Rural Livelihoods and Diversity in Developing Countries. Oxford: Oxford University Press.

Eroğlu, Ş. (2013). Extending the Resource-Based Approach to Livelihoods: An Urban Application to Turkish Gecekondu Households. International Journal of Urban and Regional Research, 37(2), 769-789.

Frongillo, J. E. A. (1999). Validation of Measures of Food Insecurity and Hunger. The Journal of Nutrition, 129(2), 506S-509S. doi:10.1093/jn/129.2.506S

Glaeser, B. (2016). From global sustainability research matrix to typology: a tool to analyze coastal and marine social-ecological systems. Regional Environmental Change, 16(2), 367-383. doi:10.1007/ s10113-015-0817-y.

Gunardo, R. B. (2004). Farming Technology, Farmers' Income and Livelihood Diversification in Kulon Progo. Forum Geografi, 13(1). https:/ / doi.org/10.23917/ forgeo.v13i1.469.

Hadley, C., \& Crooks, D. L. (2012). Coping and the biosocial consequences of food insecurity in the 21st century. 149(S55), 72-94.

Hapsari, N. I., \& Rudiarto, I. (2017). Faktor-Faktor yang Mempengaruhi Kerawanan dan Ketahanan Pangan dan Implikasi Kebijakannya di Kabupaten Rembang. 2017, 5(2), 16. doi:10.14710/ jwl.5.2.125-140.

Kristjanson, P., Radeny, M., Baltenweck, I., Ogutu, J., \& Notenbaert, A. (2005). Livelihood mapping 
and poverty correlates at a meso-level in Kenya. Food Policy, 30(5), 568-583. doi:https://doi. org/10.1016/j.foodpol.2005.10.002

Magombeyi, M. S., Taigbenu, A. E., \& Barron, J. (2016). Rural food insecurity and poverty mappings and their linkage with water resources in the Limpopo River Basin. Physics and Chemistry of the Earth, Parts $A / B / C, 92,20-33$.

Messer, L. C., Laraia, B. A., Kaufman, J. S., Eyster, J., Holzman, C., Culhane, J., O'Campo, P. (2006). The Development of a Standardized Neighborhood Deprivation Index. Journal of Urban Health, 83(6), 1041-1062. doi:10.1007/s11524-006-9094-x

Mooney, P. H., \& Hunt, S. A. (2009). Food Security: The Elaboration of Contested Claims to a Consensus Frame. Rural Sociology, 74(4), 469-497.

Noble, M., Wright, G., Smith, G., \& Dibben, C. (2006). Measuring Multiple Deprivation at the SmallArea Level. Environment and Planning A: Economy and Space, 38(1), 169-185. doi:10.1068/ a37168.

Pereira, L. M., Cuneo, C. N., \& Twine, W. C. (2014). Food and cash: understanding the role of the retail sector in rural food security in South Africa. Food Security, 6(3), 339-357. doi:10.1007/ s12571-014-0349-1.

Qudrat-I Elahi, K. (2006). Entitlement failure and deprivation: a critique of Sen's famine philosophy. The Journal of Development Studies, 42(4), 541-558. doi:10.1080/00220380600680771.

Rigg, J. (2006). Land, farming, livelihoods, and poverty: Rethinking the links in the Rural South. World Development, 34(1), 180-202. doi:https:/ / doi.org/10.1016/j.worlddev.2005.07.015

Rijanta, R. (2008). Livelihood Strategies, Responses to the Crisis, and the Role of Non-Agricultural Activities in Five Villages in the Special Region of Yogyakarta. In M. J. Titus \& P. P. M. Burgers (Eds.), Rural Livelihoods, Resources and Coping With Crisis in Indonesia. Amsterdam: Amsterdam University Press.

Ringland, G. (1998). Scenario Planning: Managing for the Future. Chichester: John Wiley \& Sons.

Rose, D. (1999). Economic Determinants and Dietary Consequences of Food Insecurity in the United States. The Journal of Nutrition, 129(2), 517S-520S. doi:10.1093/jn/129.2.517S.

Rowell, K. S. (2012). Making a Box and Whisker Plot in Excel. Retrieved from http:/ / ksrowell.com/ blog-visualizing-data/2012/08/24/making-a-box-and-whisker-plot-in-excel/.

Sen, A. (1982). Poverty and Famines: An Essay on Entitlement and Deprivation. Oxford: Oxford University Press.

Shackleton, S., Campbell, B., Lotz-Sisitka, H., \& Shackleton, C. (2008). Links between the Local Trade in Natural Products, Livelihoods and Poverty Alleviation in a Semi-arid Region of South Africa. World Development, 36(3), 505-526. doi:https://doi.org/10.1016/j. worlddev.2007.03.003

Sindo, K. (2016). 20 Desa di DIY Masih Rawan Pangan. Koran Sindo. Retrieved from http:/ / koransindo.com/page/news/2016-09-03/5/87.

SMERU. (2014). Poverty and Livelihood Map of Indonesia 2015 (online). Retrieved from: http:// povertymap.smeru.or.id

Solopos.com. (2016). Ketahanan Pangan: 20 Desa di DIY Masih Rawan Pangan. Solopos. Retrieved from http://www.solopos.com/2016/02/16/ketahanan-pangan-20-desa-di-diy-masihrawan-pangan-691588

Subejo, Fidiashtry, A., Aryudiawan, C., Suadi, Awaluddin, L., \& Marfai Muh, A. (2017). Food insecurity as a basis for drafting a Strategic Food Sovereignty Plan: A case study of the Kutai Kartanegara District, Indonesia. Quaestiones Geographicae, Vol. 36, pp. 141. 
Sutanto, A. (2008). Livelihoods and Coping Responses to the Crisis in Four Villages with Different Farm Systems in the Special Region of Yogyakarta. In M. J. Titus \& P. P. M. Burgers (Eds.), Rural Livelihoods, Resources and Coping Crisis in Indonesia: A Comparative Study. Amsterdam: Amsterdam University Press.

Toddenroth, D., Ganslandt, T., Castellanos, I., Prokosch, H.-U., \& Bürkle, T. (2014). Employing heat maps to mine associations in structured routine care data. Artificial Intelligence in Medicine, 60(2), 79-88. doi:https://doi.org/10.1016/j.artmed.2013.12.003

Tomlinson, I. (2013). Doubling food production to feed the 9 billion: A critical perspective on a key discourse of food security in the UK. Food Security, 29(Supplement C), 81-90.

Widyatmoko, D. S. (2008). The Effects of the Crisis on Livelihood Systems in "Rurban" Areas: Case Studies in the Special Region of Yogyakarta. In M. J. Titus \& P. P. M. Burgers (Eds.), Rural Livelihoods, Resources and Coping With Crisis in Indonesia. Amsterdam: Amsterdam University Press.

Appendix 1. Detail Explanation of Livelihood for Table 1.

\begin{tabular}{|c|c|c|c|}
\hline No & Indicators of Livelihood Assets & Weight & Score \\
\hline 1 & Physical Capital & & \\
\hline 1.1. & Number of Primary School & 3 & $\begin{array}{l}0=0 \\
1=\text { Low Rank } \\
2=\text { Medium Rank } \\
3=\text { High Rank }\end{array}$ \\
\hline 1.2. & Number of Junior High School & 3 & $\begin{array}{l}0=0 \\
1=\text { Low Rank } \\
2=\text { Medium Rank } \\
3=\text { High Rank }\end{array}$ \\
\hline 1.3. & Number of Senior High School & 3 & $\begin{array}{l}0=0 \\
1=\text { Low Rank } \\
2=\text { Medium Rank } \\
3=\text { High Rank }\end{array}$ \\
\hline 1.4. & $\begin{array}{l}\text { Number of Polindes (Village-Health Pos: a self-managed } \\
\text { health facility by the community which has aim on moth- } \\
\text { er and children health) }\end{array}$ & 3 & $\begin{array}{l}0=0 \\
1=\text { Low Rank } \\
2=\text { Medium Rank } \\
3=\text { High Rank }\end{array}$ \\
\hline 1.5. & $\begin{array}{l}\text { Number of Posyandu (Integrated Health Pos: a local } \\
\text { health service for the neighbourhood and supported by } \\
\text { health officers) }\end{array}$ & 3 & $\begin{array}{l}0=0 \\
1=\text { Low Rank } \\
2=\text { Medium Rank } \\
3=\text { High Rank }\end{array}$ \\
\hline 1.6. & $\begin{array}{l}\text { Number of Puskesmas (Community Health Center: a } \\
\text { health centre that has provided by the government, usu- } \\
\text { ally serve at a sub-district level) }\end{array}$ & 3 & $\begin{array}{l}0=0 \\
1=\text { Low Rank } \\
2=\text { Medium Rank } \\
3=\text { High Rank }\end{array}$ \\
\hline 1.7. & Number of Pharmacy & 3 & $\begin{array}{l}0=0 \\
1=\text { Low Rank } \\
2=\text { Medium Rank } \\
3=\text { High Rank }\end{array}$ \\
\hline 1.8. & Availability of Public Transportation & 3 & $\begin{array}{l}0=\mathrm{No} \\
3=\mathrm{Yes}\end{array}$ \\
\hline
\end{tabular}




\begin{tabular}{|c|c|c|c|}
\hline No & Indicators of Livelihood Assets & Weight & Score \\
\hline 1.9. & Village Road Can be Traversed for the Whole Year & 3 & $\begin{array}{l}0=\text { No } \\
3=\text { Yes }\end{array}$ \\
\hline 1.10 . & Availability of Cellular Signal & 3 & $\begin{array}{l}0=\mathrm{No} \\
3=\mathrm{Yes}\end{array}$ \\
\hline 1.11. & Availability of Internet Café & 1 & $\begin{array}{l}3=\text { No } \\
0=\text { Yes }\end{array}$ \\
\hline 1.12 . & Market Existence & 3 & $\begin{array}{l}0=\mathrm{No} \\
3=\mathrm{Yes}\end{array}$ \\
\hline 1.13. & Availability of Shopping Centre & 1 & $\begin{array}{l}3=\text { No } \\
0=\text { Yes }\end{array}$ \\
\hline 1.14. & Availability of Gas as Cooking Fuel & 3 & $\begin{array}{l}0=\mathrm{No} \\
3=\mathrm{Yes}\end{array}$ \\
\hline 2 & Social Capital & & \\
\hline 2.1. & The existence of Social Conflict & 3 & $\begin{array}{l}3=\text { No } \\
0=\text { Yes }\end{array}$ \\
\hline 2.2 & Number of Street Children Gathering & 1 & $\begin{array}{l}3=\mathrm{No} \\
0=\mathrm{Yes}\end{array}$ \\
\hline 3 & Natural Capital & & \\
\hline 3.1. & Ever Experiencing Natural Disasters: Landslide & 3 & $\begin{array}{l}3=\text { No } \\
0=\text { Yes }\end{array}$ \\
\hline 3.2. & Ever Experiencing Natural Disasters: Flood & 3 & $\begin{array}{l}3=\mathrm{No} \\
0=\mathrm{Yes}\end{array}$ \\
\hline 3.3. & Ever Experiencing Natural Disasters: Flash Flood & 3 & $\begin{array}{l}3=\mathrm{No} \\
0=\mathrm{Yes}\end{array}$ \\
\hline 3.4. & Ever Experiencing Natural Disasters: Forest Fire & 3 & $\begin{array}{l}3=\text { No } \\
0=\text { Yes }\end{array}$ \\
\hline 3.5. & Ever Experiencing Natural Disasters: Drought & 3 & $\begin{array}{l}3=\mathrm{No} \\
0=\mathrm{Yes}\end{array}$ \\
\hline 3.6. & Availability Safe Drinking Water Source & 3 & $\begin{array}{l}0=\mathrm{No} \\
3=\mathrm{Yes}\end{array}$ \\
\hline 3.7. & Ever Experiencing Pollution: Water & 3 & $\begin{array}{l}3=\mathrm{No} \\
0=\mathrm{Yes}\end{array}$ \\
\hline 3.8. & Ever Experiencing Pollution: Soil & 3 & $\begin{array}{l}3=\text { No } \\
0=\text { Yes }\end{array}$ \\
\hline 3.9. & Ever Experiencing Pollution: Air & 3 & $\begin{array}{l}3=\mathrm{No} \\
0=\mathrm{Yes}\end{array}$ \\
\hline 4 & Human Capital & & \\
\hline 4.1. & Migrant Workers Recruitment Agency & 1 & $\begin{array}{l}3=\text { No } \\
0=\text { Yes }\end{array}$ \\
\hline 4.2. & Number of Disabled People & 3 & $\begin{array}{l}0=0 \\
1=\text { High Rank } \\
2=\text { Medium Rank } \\
3=\text { Low Rank }\end{array}$ \\
\hline 4.3. & Agriculture as Main Working Sector & 3 & $\begin{array}{l}3=\text { Agriculture } \\
0=\text { Others }\end{array}$ \\
\hline
\end{tabular}




\begin{tabular}{|c|c|c|c|}
\hline No & Indicators of Livelihood Assets & Weight & Score \\
\hline 5 & Financial Capital & & \\
\hline 5.1. & Availability of Banking Office & 3 & $\begin{array}{l}0=\text { No } \\
3=\text { Yes }\end{array}$ \\
\hline 5.2 . & Availability of Cooperative & 3 & $\begin{array}{l}0=\text { No } \\
3=\text { Yes }\end{array}$ \\
\hline 5.3. & Availability of Credit Facilities & 3 & $\begin{array}{l}0=\mathrm{No} \\
3=\mathrm{Yes}\end{array}$ \\
\hline
\end{tabular}

Notes:

According to www.livelihoodstoolbox.org, weight should be given according to its degree of importance, a score from 1 to reflect the low significance of the asset(s) up to 3 that reflects the most important. Meanwhile, score shows its access and ownership and has a variation for its score: $0=$ low to $3=$ high. However, in this paper, I conduct two modifications. Firstly, due to its weighted value is given by implementing my subjective value and theoretical considerations rather than based on rank that is provided by local government or local people from their Focus Group Discussion. Secondly, I modify the score value because the livelihood data are grouped into two types: binary and numerical. For the binary data type, I give merely score 0 for No and 3 for Yes, except for some indicators that logically reflect good or bad condition or impact. For example, I stand for the disaster indicators are given 0 for Yes and 3 for No. Meanwhile, for the numerical data, I operate a calculation of the same interval technique. This technique measures the maximum value subtracted from the minimum value and then divided into 3 class. I give score 1 for data that including in low-rank interval, 2 for the average rank interval, and 3 for the high-rank range. A guideline from previous research paper mention that ratings are assigned based on its previous literature review explanations and author judgements (Hapsari \& Rudiarto, 2017). An exception for a zero value for a particular variable, although it is grouped into the lowclass interval, I decided to give 0 for this zero valued indicator.

Appendix 2. Local Food Plantation Area Potential.

\begin{tabular}{|c|c|c|c|c|c|c|c|c|c|c|c|c|}
\hline Village & $\begin{array}{c}\text { Geographical } \\
\text { Zone }\end{array}$ & Type & (1) & (2) & (3) & $(4)$ & (5) & (6) & (7) & (8) & (9) & (10) \\
\hline Jangkaran & Lowland & L-L & $\mathrm{L}$ & $\mathrm{M}$ & $M$ & $\mathrm{~L}$ & $\mathrm{~L}$ & $\mathrm{~L}$ & $M$ & $\mathrm{~L}$ & $\mathrm{M}$ & $\mathrm{L}$ \\
\hline Sindutan & Lowland & L-L & $\mathrm{L}$ & $\mathrm{L}$ & M & $\mathrm{L}$ & $\mathrm{M}$ & $\mathrm{L}$ & $\mathrm{L}$ & $\mathrm{L}$ & $\mathrm{L}$ & $\mathrm{L}$ \\
\hline Palihan & Lowland & L-L & $\mathrm{L}$ & $\mathrm{L}$ & M & $\mathrm{L}$ & $\mathrm{L}$ & $\mathrm{L}$ & $\mathrm{L}$ & $\mathrm{L}$ & $\mathrm{L}$ & $\mathrm{L}$ \\
\hline Glagah & Lowland & L-L & $\mathrm{L}$ & $\mathrm{M}$ & N/A & $\mathrm{L}$ & $\mathrm{L}$ & $\mathrm{L}$ & $\mathrm{M}$ & $\mathrm{L}$ & $\mathrm{L}$ & $\mathrm{L}$ \\
\hline Kalidengen & Lowland & L-L & $\mathrm{L}$ & $\mathrm{L}$ & M & $\mathrm{L}$ & $\mathrm{L}$ & $\mathrm{L}$ & $\mathrm{L}$ & $\mathrm{L}$ & $\mathrm{L}$ & $\mathrm{L}$ \\
\hline Plumbon & Lowland & $\mathrm{L}-\mathrm{L}$ & $\mathrm{L}$ & $\mathrm{L}$ & M & $\mathrm{L}$ & $\mathrm{L}$ & $\mathrm{L}$ & $\mathrm{L}$ & $\mathrm{L}$ & $\mathrm{L}$ & $\mathrm{L}$ \\
\hline Kedundang & Lowland & $\mathrm{L}-\mathrm{L}$ & $\mathrm{L}$ & $\mathrm{L}$ & M & $\mathrm{L}$ & $\mathrm{L}$ & $\mathrm{L}$ & $\mathrm{L}$ & $\mathrm{L}$ & $\mathrm{L}$ & $\mathrm{L}$ \\
\hline Demen & Lowland & L-L & $\mathrm{L}$ & $\mathrm{L}$ & M & $\mathrm{L}$ & $\mathrm{L}$ & $\mathrm{L}$ & $\mathrm{L}$ & $\mathrm{L}$ & $\mathrm{L}$ & $\mathrm{L}$ \\
\hline Kulur & Lowland & L-L & $\mathrm{L}$ & $\mathrm{M}$ & M & $\mathrm{L}$ & $\mathrm{M}$ & $\mathrm{L}$ & $\mathrm{L}$ & $\mathrm{L}$ & $\mathrm{L}$ & $\mathrm{L}$ \\
\hline Kaligintung & Lowland & L-L & $\mathrm{L}$ & M & M & $\mathrm{L}$ & $\mathrm{M}$ & $\mathrm{L}$ & $\mathrm{L}$ & $\mathrm{L}$ & $\mathrm{L}$ & $\mathrm{L}$ \\
\hline Temon Wetan & Lowland & $\mathrm{L}-\mathrm{L}$ & $\mathrm{L}$ & $\mathrm{L}$ & N/A & $\mathrm{L}$ & $\mathrm{M}$ & $\mathrm{L}$ & $\mathrm{L}$ & $\mathrm{L}$ & $\mathrm{L}$ & $\mathrm{L}$ \\
\hline Temon Kulon & Lowland & L-L & $\mathrm{L}$ & $\mathrm{L}$ & M & $\mathrm{L}$ & $\mathrm{M}$ & $\mathrm{L}$ & $\mathrm{L}$ & $\mathrm{L}$ & $\mathrm{L}$ & M \\
\hline Kebonrejo & Lowland & L-L & $\mathrm{L}$ & $\mathrm{L}$ & M & $\mathrm{L}$ & $\mathrm{L}$ & $\mathrm{L}$ & $\mathrm{L}$ & $\mathrm{L}$ & $\mathrm{L}$ & $\mathrm{L}$ \\
\hline Janten & Lowland & L-L & $\mathrm{L}$ & $\mathrm{L}$ & M & $\mathrm{L}$ & $\mathrm{L}$ & $\mathrm{L}$ & $\mathrm{L}$ & $\mathrm{L}$ & $\mathrm{L}$ & $\mathrm{L}$ \\
\hline Karang Wuluh & Lowland & L-L & $\mathrm{L}$ & $\mathrm{L}$ & M & $\mathrm{L}$ & $\mathrm{L}$ & $\mathrm{L}$ & $\mathrm{L}$ & $\mathrm{L}$ & $\mathrm{L}$ & $\mathrm{L}$ \\
\hline Karangwuni & Lowland & M-L & $\mathrm{L}$ & $\mathrm{L}$ & M & $\mathrm{M}$ & $\mathrm{L}$ & $\mathrm{L}$ & $\mathrm{L}$ & $\mathrm{L}$ & $\mathrm{M}$ & $\mathrm{L}$ \\
\hline Sogan & Lowland & $\mathrm{L}-\mathrm{L}$ & $\mathrm{L}$ & $\mathrm{L}$ & $\mathrm{L}$ & $\mathrm{M}$ & $\mathrm{L}$ & $\mathrm{L}$ & $\mathrm{L}$ & $\mathrm{L}$ & M & $\mathrm{L}$ \\
\hline
\end{tabular}




\begin{tabular}{|c|c|c|c|c|c|c|c|c|c|c|c|c|}
\hline Village & $\begin{array}{c}\text { Geographical } \\
\text { Zone }\end{array}$ & Type & (1) & (2) & (3) & $(4)$ & (5) & (6) & (7) & (8) & (9) & (10) \\
\hline Kulwaru & Lowland & L-L & $\mathrm{L}$ & M & M & M & $\mathrm{L}$ & M & $\mathrm{L}$ & M & $\mathrm{L}$ & $\mathrm{L}$ \\
\hline Ngestiharjo & Lowland & M-L & $\mathrm{L}$ & $\mathrm{L}$ & M & M & M & $\mathrm{L}$ & $\mathrm{L}$ & M & M & $\mathrm{L}$ \\
\hline Triharjo & Lowland & M-L & $\mathrm{L}$ & $\mathrm{L}$ & M & M & M & $\mathrm{L}$ & $\mathrm{L}$ & $\mathrm{L}$ & M & $\mathrm{L}$ \\
\hline Bendungan & Lowland & $\mathrm{H}-\mathrm{M}$ & $\mathrm{L}$ & $\mathrm{L}$ & M & M & M & M & $\mathrm{L}$ & M & M & $\mathrm{L}$ \\
\hline Giripeni & Lowland & $\mathrm{M}-\mathrm{H}$ & $\mathrm{L}$ & M & M & $\mathrm{L}$ & M & $\mathrm{L}$ & $\mathrm{L}$ & M & M & $\mathrm{L}$ \\
\hline Wates & Lowland & $\mathrm{M}-\mathrm{H}$ & $\mathrm{L}$ & $\mathrm{L}$ & $\mathrm{L}$ & $\mathrm{L}$ & $\mathrm{L}$ & $\mathrm{L}$ & $\mathrm{L}$ & $\mathrm{L}$ & M & $\mathrm{L}$ \\
\hline Garongan & Lowland & L-L & $\mathrm{L}$ & $\mathrm{H}$ & $\mathrm{L}$ & $\mathrm{L}$ & $\mathrm{L}$ & $\mathrm{L}$ & $\mathrm{H}$ & $\mathrm{L}$ & M & $\mathrm{L}$ \\
\hline Pleret & Lowland & L-L & $\mathrm{L}$ & $\mathrm{H}$ & $\mathrm{L}$ & $\mathrm{L}$ & $\mathrm{L}$ & $\mathrm{L}$ & M & $\mathrm{L}$ & M & $\mathrm{L}$ \\
\hline Bugel & Lowland & L-L & $\mathrm{L}$ & $\mathrm{H}$ & $\mathrm{L}$ & $\mathrm{L}$ & $\mathrm{L}$ & $\mathrm{L}$ & M & $\mathrm{L}$ & M & $\mathrm{L}$ \\
\hline Kanoman & Lowland & L-L & $\mathrm{L}$ & $\mathrm{L}$ & $\mathrm{H}$ & $\mathrm{L}$ & $\mathrm{L}$ & $\mathrm{L}$ & $\mathrm{L}$ & $\mathrm{L}$ & M & $\mathrm{L}$ \\
\hline Depok & Lowland & $\mathrm{L}-\mathrm{L}$ & $\mathrm{L}$ & $\mathrm{L}$ & $\mathrm{L}$ & $\mathrm{L}$ & $\mathrm{L}$ & $\mathrm{L}$ & $\mathrm{L}$ & M & M & $\mathrm{L}$ \\
\hline Bojong & Lowland & L-L & $\mathrm{L}$ & M & M & $\mathrm{L}$ & $\mathrm{L}$ & $\mathrm{L}$ & $\mathrm{L}$ & M & M & M \\
\hline Tayuban & Lowland & M-L & $\mathrm{L}$ & M & M & $\mathrm{L}$ & M & $\mathrm{L}$ & $\mathrm{L}$ & M & M & $\mathrm{L}$ \\
\hline Gotakan & Lowland & $\mathrm{H}-\mathrm{L}$ & $\mathrm{L}$ & $\mathrm{L}$ & M & $\mathrm{L}$ & M & $\mathrm{L}$ & $\mathrm{L}$ & $\mathrm{L}$ & M & M \\
\hline Panjatan & Lowland & L-L & $\mathrm{L}$ & $\mathrm{L}$ & $\mathrm{L}$ & $\mathrm{L}$ & M & $\mathrm{L}$ & $\mathrm{L}$ & M & M & M \\
\hline Cerme & Lowland & L-L & $\mathrm{L}$ & $\mathrm{L}$ & $\mathrm{L}$ & $\mathrm{L}$ & $\mathrm{L}$ & $\mathrm{L}$ & $\mathrm{H}$ & M & M & $\mathrm{L}$ \\
\hline Krembangan & Lowland & $\mathrm{L}-\mathrm{L}$ & $\mathrm{L}$ & $\mathrm{L}$ & $\mathrm{L}$ & $\mathrm{L}$ & $\mathrm{L}$ & $\mathrm{L}$ & $\mathrm{L}$ & $\mathrm{L}$ & M & $\mathrm{L}$ \\
\hline Karangsewu & Lowland & L-L & $\mathrm{L}$ & M & M & M & M & $\mathrm{L}$ & M & M & M & $\mathrm{L}$ \\
\hline Banaran & Lowland & M-L & $\mathrm{L}$ & M & M & M & M & $\mathrm{L}$ & M & M & M & M \\
\hline Kranggan & Lowland & $\mathrm{L}-\mathrm{L}$ & $\mathrm{L}$ & M & M & $\mathrm{L}$ & M & $\mathrm{L}$ & $\mathrm{L}$ & M & M & $\mathrm{L}$ \\
\hline Nomporejo & Lowland & M-L & $\mathrm{L}$ & M & M & $\mathrm{L}$ & M & $\mathrm{L}$ & $\mathrm{L}$ & M & M & M \\
\hline Brosot & Lowland & M-L & $\mathrm{L}$ & $\mathrm{L}$ & M & $\mathrm{L}$ & $\mathrm{L}$ & $\mathrm{L}$ & $\mathrm{L}$ & $\mathrm{L}$ & M & M \\
\hline Pandowan & Lowland & L-L & $\mathrm{L}$ & M & M & $\mathrm{L}$ & M & $\mathrm{L}$ & $\mathrm{L}$ & M & M & $\mathrm{L}$ \\
\hline Tirtorahayu & Lowland & M-L & $\mathrm{L}$ & $\mathrm{L}$ & M & M & M & $\mathrm{L}$ & M & M & M & $\mathrm{L}$ \\
\hline Wahyuharjo & Lowland & L-L & N/A & N/A & N/A & N/A & N/A & N/A & N/A & N/A & N/A & N/A \\
\hline Bumirejo & Lowland & $\mathrm{L}-\mathrm{L}$ & $\mathrm{L}$ & $\mathrm{L}$ & M & $\mathrm{L}$ & $\mathrm{L}$ & $\mathrm{L}$ & $\mathrm{L}$ & M & $\mathrm{L}$ & M \\
\hline Jatirejo & Lowland & L-L & $\mathrm{L}$ & $\mathrm{L}$ & M & M & M & M & $\mathrm{L}$ & M & M & M \\
\hline Sidorejo & Lowland & $\mathrm{H}-\mathrm{L}$ & $\mathrm{H}$ & M & M & $\mathrm{H}$ & $\mathrm{H}$ & $\mathrm{H}$ & $\mathrm{H}$ & $\mathrm{H}$ & $\mathrm{H}$ & $\mathrm{H}$ \\
\hline Gulurejo & Lowland & M-L & $\mathrm{L}$ & $\mathrm{L}$ & M & $\mathrm{H}$ & M & M & $\mathrm{L}$ & $\mathrm{H}$ & $\mathrm{H}$ & M \\
\hline Ngentakrejo & Lowland & $\mathrm{H}-\mathrm{L}$ & $\mathrm{L}$ & $\mathrm{L}$ & $\mathrm{L}$ & M & $\mathrm{L}$ & $\mathrm{L}$ & $\mathrm{L}$ & $\mathrm{L}$ & $\mathrm{L}$ & $\mathrm{L}$ \\
\hline Demangrejo & Transitional & $\mathrm{L}-\mathrm{L}$ & N/A & N/A & N/A & N/A & $\mathrm{N} / \mathrm{A}$ & $\mathrm{N} / \mathrm{A}$ & N/A & N/A & $\mathrm{N} / \mathrm{A}$ & N/A \\
\hline Srikayangan & Transitional & M-L & $\mathrm{L}$ & $\mathrm{L}$ & $\mathrm{L}$ & $\mathrm{L}$ & $\mathrm{L}$ & $\mathrm{L}$ & $\mathrm{L}$ & $\mathrm{L}$ & $\mathrm{L}$ & $\mathrm{L}$ \\
\hline Tuksono & Transitional & $\mathrm{M}-\mathrm{H}$ & $\mathrm{L}$ & $\mathrm{L}$ & $\mathrm{L}$ & $\mathrm{L}$ & $\mathrm{L}$ & $\mathrm{L}$ & $\mathrm{L}$ & $\mathrm{L}$ & $\mathrm{L}$ & $\mathrm{L}$ \\
\hline Salamrejo & Transitional & L-L & $\mathrm{L}$ & $\mathrm{L}$ & $\mathrm{L}$ & $\mathrm{L}$ & $\mathrm{L}$ & $\mathrm{L}$ & $\mathrm{L}$ & $\mathrm{L}$ & $\mathrm{L}$ & $\mathrm{L}$ \\
\hline Sukoreno & Transitional & $\mathrm{L}-\mathrm{L}$ & N/A & N/A & N/A & N/A & N/A & N/A & N/A & N/A & N/A & N/A \\
\hline Kaliagung & Transitional & M-L & $\mathrm{L}$ & $\mathrm{L}$ & $\mathrm{L}$ & $\mathrm{L}$ & $\mathrm{L}$ & $\mathrm{L}$ & $\mathrm{L}$ & $\mathrm{L}$ & $\mathrm{L}$ & $\mathrm{L}$ \\
\hline Sentolo & Transitional & $\mathrm{H}-\mathrm{L}$ & N/A & N/A & N/A & N/A & N/A & $\mathrm{N} / \mathrm{A}$ & N/A & N/A & N/A & N/A \\
\hline Banguncipto & Transitional & M-L & $\mathrm{L}$ & $\mathrm{L}$ & $\mathrm{L}$ & $\mathrm{L}$ & $\mathrm{L}$ & $\mathrm{L}$ & $\mathrm{L}$ & $\mathrm{L}$ & $\mathrm{L}$ & $\mathrm{L}$ \\
\hline Tawangsari & Transitional & L-L & N/A & N/A & N/A & N/A & N/A & N/A & N/A & $\mathrm{N} / \mathrm{A}$ & N/A & N/A \\
\hline Karangsari & Transitional & $\mathrm{H}-\mathrm{L}$ & $\mathrm{L}$ & $\mathrm{L}$ & $\mathrm{L}$ & $\mathrm{L}$ & $\mathrm{L}$ & $\mathrm{L}$ & $\mathrm{L}$ & $\mathrm{L}$ & $\mathrm{L}$ & $\mathrm{L}$ \\
\hline Kedungsari & Transitional & M-L & $\mathrm{L}$ & $\mathrm{L}$ & $\mathrm{L}$ & $\mathrm{L}$ & $\mathrm{L}$ & $\mathrm{L}$ & $\mathrm{L}$ & $\mathrm{L}$ & $\mathrm{L}$ & $\mathrm{L}$ \\
\hline Margosari & Transitional & M-L & $\mathrm{L}$ & $\mathrm{L}$ & $\mathrm{L}$ & $\mathrm{L}$ & $\mathrm{L}$ & $\mathrm{L}$ & $\mathrm{L}$ & $\mathrm{L}$ & $\mathrm{L}$ & $\mathrm{L}$ \\
\hline Pengasih & Transitional & $\mathrm{H}-\mathrm{M}$ & N/A & N/A & N/A & N/A & N/A & $\mathrm{N} / \mathrm{A}$ & N/A & N/A & $\mathrm{N} / \mathrm{A}$ & N/A \\
\hline Sendangsari & Transitional & $\mathrm{L}-\mathrm{L}$ & $\mathrm{L}$ & $\mathrm{L}$ & $\mathrm{L}$ & $\mathrm{L}$ & $\mathrm{L}$ & $\mathrm{L}$ & $\mathrm{L}$ & $\mathrm{L}$ & $\mathrm{L}$ & $\mathrm{L}$ \\
\hline Sidomulyo & Transitional & M-L & $\mathrm{L}$ & $\mathrm{L}$ & $\mathrm{L}$ & $\mathrm{L}$ & $\mathrm{L}$ & $\mathrm{L}$ & $\mathrm{L}$ & $\mathrm{L}$ & $\mathrm{L}$ & $\mathrm{L}$ \\
\hline Hargomulyo & Transitional & M-L & $\mathrm{H}$ & $\mathrm{L}$ & M & M & M & M & $\mathrm{L}$ & M & M & M \\
\hline
\end{tabular}




\begin{tabular}{|c|c|c|c|c|c|c|c|c|c|c|c|c|}
\hline Village & $\begin{array}{c}\text { Geographical } \\
\text { Zone }\end{array}$ & Type & (1) & $(2)$ & (3) & $(4)$ & $(5)$ & (6) & (7) & (8) & (9) & (10) \\
\hline Hargorejo & Transitional & L-L & $\mathrm{H}$ & $\mathrm{L}$ & M & M & M & M & $\mathrm{L}$ & M & M & $\mathrm{H}$ \\
\hline Hargowilis & Transitional & $\mathrm{M}-\mathrm{H}$ & $\mathrm{H}$ & $\mathrm{L}$ & M & M & $\mathrm{M}$ & $\mathrm{L}$ & $\mathrm{L}$ & M & $\mathrm{L}$ & M \\
\hline Kalirejo & Transitional & M-M & M & $\mathrm{L}$ & M & $\mathrm{L}$ & $\mathrm{M}$ & $\mathrm{L}$ & $\mathrm{L}$ & M & $\mathrm{L}$ & M \\
\hline Hargotirto & Transitional & M-H & M & $\mathrm{L}$ & M & $\mathrm{L}$ & M & $\mathrm{L}$ & $\mathrm{L}$ & M & $\mathrm{L}$ & M \\
\hline Jatimulyo & Transitional & $\mathrm{H}-\mathrm{L}$ & M & $\mathrm{L}$ & M & $\mathrm{L}$ & $\mathrm{L}$ & $\mathrm{L}$ & $\mathrm{L}$ & M & $\mathrm{N} / \mathrm{A}$ & M \\
\hline Giripurwo & Transitional & $\mathrm{H}-\mathrm{H}$ & $\mathrm{L}$ & $\mathrm{L}$ & $\mathrm{L}$ & $\mathrm{L}$ & $\mathrm{L}$ & $\mathrm{L}$ & $\mathrm{L}$ & $\mathrm{L}$ & $\mathrm{L}$ & $\mathrm{L}$ \\
\hline Pendoworejo & Upland & M-L & M & $\mathrm{M}$ & M & M & $\mathrm{M}$ & $\mathrm{L}$ & $\mathrm{L}$ & $\mathrm{L}$ & N/A & M \\
\hline Purwosari & Upland & M-L & M & $\mathrm{H}$ & M & $\mathrm{L}$ & $\mathrm{N} / \mathrm{A}$ & N/A & $\mathrm{L}$ & M & N/A & M \\
\hline Banyuroto & Upland & M-L & $\mathrm{L}$ & $\mathrm{L}$ & $\mathrm{L}$ & $\mathrm{L}$ & $\mathrm{L}$ & $\mathrm{L}$ & $\mathrm{L}$ & $\mathrm{L}$ & $\mathrm{L}$ & $\mathrm{L}$ \\
\hline Donomulyo & Upland & $\mathrm{H}-\mathrm{L}$ & $\mathrm{L}$ & $\mathrm{L}$ & $\mathrm{L}$ & $\mathrm{L}$ & $\mathrm{L}$ & $\mathrm{L}$ & $\mathrm{L}$ & $\mathrm{L}$ & $\mathrm{L}$ & $\mathrm{L}$ \\
\hline Wijimulyo & Upland & L-L & $\mathrm{L}$ & $\mathrm{L}$ & $\mathrm{L}$ & $\mathrm{L}$ & $\mathrm{L}$ & $\mathrm{L}$ & $\mathrm{L}$ & $\mathrm{L}$ & $\mathrm{L}$ & $\mathrm{L}$ \\
\hline Tanjungharjo & Upland & M-L & $\mathrm{L}$ & $\mathrm{L}$ & $\mathrm{L}$ & $\mathrm{L}$ & $\mathrm{L}$ & $\mathrm{L}$ & $\mathrm{L}$ & $\mathrm{L}$ & $\mathrm{L}$ & $\mathrm{L}$ \\
\hline Jatisarono & Upland & L-L & $\mathrm{N} / \mathrm{A}$ & $\mathrm{N} / \mathrm{A}$ & $\mathrm{N} / \mathrm{A}$ & N/A & N/A & N/A & N/A & N/A & $\mathrm{N} / \mathrm{A}$ & $\mathrm{N} / \mathrm{A}$ \\
\hline Kembang & Upland & L-L & $\mathrm{L}$ & $\mathrm{L}$ & $\mathrm{L}$ & $\mathrm{L}$ & $\mathrm{L}$ & $\mathrm{L}$ & $\mathrm{L}$ & $\mathrm{L}$ & $\mathrm{L}$ & $\mathrm{L}$ \\
\hline Banjararum & Upland & M-L & $\mathrm{L}$ & $\mathrm{L}$ & $\mathrm{L}$ & $\mathrm{L}$ & $\mathrm{L}$ & $\mathrm{L}$ & $\mathrm{L}$ & $\mathrm{L}$ & $\mathrm{L}$ & $\mathrm{L}$ \\
\hline Banjarasri & Upland & L-L & $\mathrm{L}$ & $\mathrm{L}$ & $\mathrm{L}$ & $\mathrm{L}$ & $\mathrm{L}$ & $\mathrm{L}$ & $\mathrm{L}$ & $\mathrm{L}$ & $\mathrm{L}$ & $\mathrm{L}$ \\
\hline Banjarharjo & Upland & $\mathrm{H}-\mathrm{L}$ & $\mathrm{L}$ & $\mathrm{L}$ & $\mathrm{L}$ & $\mathrm{L}$ & $\mathrm{L}$ & $\mathrm{L}$ & $\mathrm{L}$ & $\mathrm{L}$ & $\mathrm{L}$ & $\mathrm{L}$ \\
\hline Banjaroya & Upland & M-L & $\mathrm{L}$ & $\mathrm{L}$ & $\mathrm{L}$ & $\mathrm{L}$ & $\mathrm{L}$ & $\mathrm{L}$ & $\mathrm{L}$ & $\mathrm{L}$ & $\mathrm{L}$ & $\mathrm{L}$ \\
\hline Kebonharjo & Upland & $\mathrm{H}-\mathrm{L}$ & M & $\mathrm{L}$ & N/A & N/A & N/A & N/A & N/A & N/A & N/A & N/A \\
\hline Banjarsari & Upland & M-L & M & M & $\mathrm{H}$ & M & M & M & $\mathrm{L}$ & M & M & $\mathrm{H}$ \\
\hline Purwoharjo & Upland & $\mathrm{H}-\mathrm{H}$ & M & $\mathrm{L}$ & M & M & M & $\mathrm{L}$ & $\mathrm{L}$ & $\mathrm{L}$ & M & M \\
\hline Sidoharjo & Upland & $\mathrm{L}-\mathrm{H}$ & N/A & N/A & N/A & N/A & N/A & N/A & N/A & N/A & N/A & N/A \\
\hline Gerbosari & Upland & M-L & $\mathrm{L}$ & M & M & M & M & M & M & M & M & $\mathrm{H}$ \\
\hline Ngargosari & Upland & $\mathrm{M}-\mathrm{H}$ & $\mathrm{L}$ & $\mathrm{M}$ & $\mathrm{L}$ & $\mathrm{L}$ & $\mathrm{L}$ & $\mathrm{L}$ & $\mathrm{L}$ & $\mathrm{L}$ & $\mathrm{L}$ & $\mathrm{L}$ \\
\hline Pagerharjo & Upland & L-M & $\mathrm{L}$ & M & M & M & M & M & M & M & M & $\mathrm{H}$ \\
\hline
\end{tabular}

1. Sign of the colour show the class difference among local food production, darker color shows higher class. Meanwhile, $\mathrm{N} / \mathrm{A}=\mathrm{No}$ Data, $\mathrm{L}=\mathrm{Low}, \mathrm{M}=$ Medium, $\mathrm{H}=$ High. This visualisation adopt the idea of heat map result (Toddenroth, et al., 2014), but I tabulate manually for the presentation.

2. The name of local food crops: (1) cassava/ubi kayu; (2) sweet potato/ubi jalar; (3) edible canna/ ganyong; (4) arrowroot/garut; (5) prasina/gadung; (6) birch rim yam/gembili; (7) pumpkin/ labu kuning; (8) tuber/uwi; (9) bread fruit/ sukun; (10) elephant's foot/suweg.

Appendix 3. Local Food Production Potential.

\begin{tabular}{lllllllllllll}
\hline \multicolumn{1}{c}{ Village } & $\begin{array}{c}\text { Geographical } \\
\text { Zone }\end{array}$ & Type & $\mathbf{( 1 )}$ & $\mathbf{( 2 )}$ & $\mathbf{( 3 )}$ & $\mathbf{( 4 )}$ & $\mathbf{( 5 )}$ & $\mathbf{( 6 )}$ & $\mathbf{( 7 )}$ & $\mathbf{( 8 )}$ & $\mathbf{( 9 )}$ & $\mathbf{( 1 0 )}$ \\
\hline Jangkaran & Lowland & $\mathrm{L}-\mathrm{L}$ & $\mathrm{L}$ & $\mathrm{L}$ & $\mathrm{M}$ & $\mathrm{L}$ & $\mathrm{L}$ & $\mathrm{L}$ & $\mathrm{H}$ & $\mathrm{L}$ & $\mathrm{M}$ & $\mathrm{L}$ \\
Sindutan & Lowland & $\mathrm{L}-\mathrm{L}$ & $\mathrm{L}$ & $\mathrm{L}$ & $\mathrm{L}$ & $\mathrm{L}$ & $\mathrm{L}$ & $\mathrm{L}$ & $\mathrm{M}$ & $\mathrm{L}$ & $\mathrm{L}$ & $\mathrm{L}$ \\
Palihan & Lowland & $\mathrm{L}-\mathrm{L}$ & $\mathrm{L}$ & $\mathrm{L}$ & $\mathrm{L}$ & $\mathrm{L}$ & $\mathrm{L}$ & $\mathrm{L}$ & $\mathrm{L}$ & $\mathrm{L}$ & $\mathrm{L}$ & $\mathrm{L}$ \\
Glagah & Lowland & $\mathrm{L}-\mathrm{L}$ & $\mathrm{N} / \mathrm{A}$ & $\mathrm{L}$ & $\mathrm{N} / \mathrm{A}$ & $\mathrm{L}$ & $\mathrm{L}$ & $\mathrm{L}$ & $\mathrm{L}$ & $\mathrm{L}$ & $\mathrm{L}$ & $\mathrm{L}$ \\
Kalidengen & Lowland & $\mathrm{L}-\mathrm{L}$ & $\mathrm{L}$ & $\mathrm{L}$ & $\mathrm{L}$ & $\mathrm{L}$ & $\mathrm{L}$ & $\mathrm{L}$ & $\mathrm{M}$ & $\mathrm{L}$ & $\mathrm{L}$ & $\mathrm{L}$ \\
Plumbon & Lowland & $\mathrm{L}-\mathrm{L}$ & $\mathrm{L}$ & $\mathrm{L}$ & $\mathrm{L}$ & $\mathrm{L}$ & $\mathrm{L}$ & $\mathrm{L}$ & $\mathrm{M}$ & $\mathrm{L}$ & $\mathrm{L}$ & $\mathrm{L}$ \\
Kedundang & Lowland & $\mathrm{L}-\mathrm{L}$ & $\mathrm{L}$ & $\mathrm{L}$ & $\mathrm{L}$ & $\mathrm{L}$ & $\mathrm{L}$ & $\mathrm{L}$ & $\mathrm{L}$ & $\mathrm{L}$ & $\mathrm{L}$ & $\mathrm{L}$ \\
Demen & Lowland & $\mathrm{L}-\mathrm{L}$ & $\mathrm{L}$ & $\mathrm{L}$ & $\mathrm{L}$ & $\mathrm{L}$ & $\mathrm{L}$ & $\mathrm{L}$ & $\mathrm{M}$ & $\mathrm{L}$ & $\mathrm{L}$ & $\mathrm{L}$ \\
Kulur & Lowland & $\mathrm{L}-\mathrm{L}$ & $\mathrm{L}$ & $\mathrm{L}$ & $\mathrm{L}$ & $\mathrm{L}$ & $\mathrm{M}$ & $\mathrm{L}$ & $\mathrm{L}$ & $\mathrm{L}$ & $\mathrm{L}$ & $\mathrm{L}$ \\
Kaligintung & Lowland & $\mathrm{L}-\mathrm{L}$ & $\mathrm{L}$ & $\mathrm{L}$ & $\mathrm{L}$ & $\mathrm{L}$ & $\mathrm{L}$ & $\mathrm{L}$ & $\mathrm{M}$ & $\mathrm{L}$ & $\mathrm{L}$ & $\mathrm{L}$ \\
Temon Wetan & Lowland & $\mathrm{L}-\mathrm{L}$ & $\mathrm{L}$ & $\mathrm{L}$ & $\mathrm{N} / \mathrm{A}$ & $\mathrm{L}$ & $\mathrm{L}$ & $\mathrm{L}$ & $\mathrm{L}$ & $\mathrm{L}$ & $\mathrm{L}$ & $\mathrm{L}$ \\
\hline
\end{tabular}




\begin{tabular}{|c|c|c|c|c|c|c|c|c|c|c|c|c|}
\hline Village & $\begin{array}{c}\text { Geographical } \\
\text { Zone }\end{array}$ & Type & (1) & (2) & (3) & (4) & (5) & $(6)$ & (7) & (8) & (9) & (10) \\
\hline Temon Kulon & Lowland & L-L & $\mathrm{L}$ & $\mathrm{L}$ & $\mathrm{L}$ & $\mathrm{L}$ & $\mathrm{L}$ & $\mathrm{L}$ & $\mathrm{L}$ & $\mathrm{L}$ & $\mathrm{L}$ & $\mathrm{L}$ \\
\hline Kebonrejo & Lowland & L-L & $\mathrm{L}$ & $\mathrm{L}$ & $\mathrm{L}$ & $\mathrm{L}$ & $\mathrm{L}$ & $\mathrm{L}$ & $\mathrm{L}$ & $\mathrm{L}$ & $\mathrm{L}$ & $\mathrm{L}$ \\
\hline Janten & Lowland & L-L & $\mathrm{L}$ & $\mathrm{L}$ & $\mathrm{L}$ & $\mathrm{L}$ & $\mathrm{L}$ & $\mathrm{L}$ & M & $\mathrm{L}$ & $\mathrm{L}$ & $\mathrm{L}$ \\
\hline Karang Wuluh & Lowland & L-L & $\mathrm{L}$ & $\mathrm{L}$ & $\mathrm{L}$ & $\mathrm{L}$ & $\mathrm{L}$ & $\mathrm{L}$ & M & $\mathrm{L}$ & $\mathrm{L}$ & $\mathrm{L}$ \\
\hline Karangwuni & Lowland & M-L & $\mathrm{L}$ & $\mathrm{L}$ & $\mathrm{L}$ & $\mathrm{L}$ & $\mathrm{L}$ & $\mathrm{L}$ & $\mathrm{L}$ & $\mathrm{L}$ & M & $\mathrm{L}$ \\
\hline Sogan & Lowland & L-L & $\mathrm{L}$ & $\mathrm{L}$ & $\mathrm{L}$ & M & $\mathrm{L}$ & $\mathrm{L}$ & $\mathrm{L}$ & $\mathrm{L}$ & $\mathrm{L}$ & $\mathrm{L}$ \\
\hline Kulwaru & Lowland & L-L & $\mathrm{L}$ & M & $\mathrm{L}$ & M & $\mathrm{L}$ & $\mathrm{L}$ & $\mathrm{L}$ & M & $\mathrm{L}$ & $\mathrm{L}$ \\
\hline Ngestiharjo & Lowland & M-L & $\mathrm{L}$ & $\mathrm{L}$ & M & $\mathrm{L}$ & $\mathrm{L}$ & $\mathrm{L}$ & $\mathrm{L}$ & $\mathrm{L}$ & $\mathrm{M}$ & $\mathrm{L}$ \\
\hline Triharjo & Lowland & M-L & $\mathrm{L}$ & $\mathrm{L}$ & M & M & $\mathrm{L}$ & $\mathrm{L}$ & $\mathrm{L}$ & $\mathrm{L}$ & M & $\mathrm{L}$ \\
\hline Bendungan & Lowland & H-M & $\mathrm{L}$ & $\mathrm{L}$ & $\mathrm{L}$ & $\mathrm{L}$ & $\mathrm{L}$ & $\mathrm{L}$ & $\mathrm{L}$ & $\mathrm{L}$ & M & $\mathrm{L}$ \\
\hline Giripeni & Lowland & M-H & $\mathrm{L}$ & M & M & $\mathrm{L}$ & $\mathrm{L}$ & $\mathrm{L}$ & $\mathrm{L}$ & M & $\mathrm{L}$ & $\mathrm{L}$ \\
\hline Wates & Lowland & $\mathrm{M}-\mathrm{H}$ & $\mathrm{L}$ & $\mathrm{L}$ & $\mathrm{L}$ & M & $\mathrm{L}$ & $\mathrm{L}$ & $\mathrm{L}$ & $\mathrm{L}$ & M & $\mathrm{L}$ \\
\hline Garongan & Lowland & L-L & $\mathrm{L}$ & $\mathrm{L}$ & $\mathrm{L}$ & $\mathrm{L}$ & $\mathrm{L}$ & $\mathrm{L}$ & M & $\mathrm{L}$ & $\mathrm{L}$ & $\mathrm{L}$ \\
\hline Pleret & Lowland & L-L & $\mathrm{L}$ & $\mathrm{L}$ & $\mathrm{L}$ & $\mathrm{L}$ & $\mathrm{L}$ & $\mathrm{L}$ & $\mathrm{L}$ & $\mathrm{L}$ & $\mathrm{L}$ & $\mathrm{L}$ \\
\hline Bugel & Lowland & $\mathrm{L}-\mathrm{L}$ & $\mathrm{L}$ & $\mathrm{L}$ & $\mathrm{L}$ & $\mathrm{L}$ & $\mathrm{L}$ & $\mathrm{L}$ & $\mathrm{L}$ & $\mathrm{L}$ & $\mathrm{L}$ & $\mathrm{L}$ \\
\hline Kanoman & Lowland & L-L & $\mathrm{L}$ & $\mathrm{L}$ & $\mathrm{L}$ & $\mathrm{L}$ & $\mathrm{L}$ & $\mathrm{L}$ & $\mathrm{L}$ & $\mathrm{L}$ & $\mathrm{L}$ & $\mathrm{L}$ \\
\hline Depok & Lowland & $\mathrm{L}-\mathrm{L}$ & $\mathrm{L}$ & $\mathrm{L}$ & $\mathrm{L}$ & $\mathrm{L}$ & $\mathrm{L}$ & $\mathrm{L}$ & $\mathrm{L}$ & $\mathrm{L}$ & $\mathrm{L}$ & $\mathrm{L}$ \\
\hline Bojong & Lowland & L-L & $\mathrm{L}$ & $\mathrm{L}$ & $\mathrm{L}$ & $\mathrm{L}$ & $\mathrm{L}$ & $\mathrm{L}$ & $\mathrm{L}$ & $\mathrm{L}$ & $\mathrm{L}$ & $\mathrm{L}$ \\
\hline Tayuban & Lowland & M-L & $\mathrm{L}$ & $\mathrm{L}$ & $\mathrm{L}$ & $\mathrm{L}$ & $\mathrm{L}$ & $\mathrm{L}$ & $\mathrm{L}$ & $\mathrm{L}$ & $\mathrm{L}$ & $\mathrm{L}$ \\
\hline Gotakan & Lowland & H-L & $\mathrm{L}$ & $\mathrm{L}$ & $\mathrm{L}$ & $\mathrm{L}$ & $\mathrm{L}$ & $\mathrm{L}$ & $\mathrm{L}$ & $\mathrm{L}$ & $\mathrm{L}$ & $\mathrm{L}$ \\
\hline Panjatan & Lowland & L-L & $\mathrm{L}$ & $\mathrm{L}$ & $\mathrm{L}$ & $\mathrm{L}$ & $\mathrm{L}$ & $\mathrm{L}$ & $\mathrm{L}$ & $\mathrm{L}$ & $\mathrm{L}$ & $\mathrm{L}$ \\
\hline Cerme & Lowland & L-L & $\mathrm{L}$ & $\mathrm{L}$ & $\mathrm{L}$ & $\mathrm{L}$ & $\mathrm{L}$ & $\mathrm{L}$ & $\mathrm{L}$ & $\mathrm{L}$ & $\mathrm{L}$ & $\mathrm{L}$ \\
\hline Krembangan & Lowland & L-L & $\mathrm{L}$ & $\mathrm{L}$ & $\mathrm{L}$ & $\mathrm{L}$ & $\mathrm{L}$ & $\mathrm{L}$ & $\mathrm{L}$ & $\mathrm{L}$ & $\mathrm{L}$ & $\mathrm{L}$ \\
\hline Karangsewu & Lowland & L-L & $\mathrm{L}$ & M & M & $\mathrm{L}$ & $\mathrm{L}$ & $\mathrm{L}$ & M & M & M & $\mathrm{L}$ \\
\hline Banaran & Lowland & M-L & $\mathrm{L}$ & M & M & $\mathrm{L}$ & $\mathrm{L}$ & $\mathrm{L}$ & M & $\mathrm{L}$ & M & $\mathrm{L}$ \\
\hline Kranggan & Lowland & L-L & $\mathrm{L}$ & M & M & $\mathrm{L}$ & $\mathrm{L}$ & $\mathrm{L}$ & $\mathrm{L}$ & $\mathrm{L}$ & M & M \\
\hline Nomporejo & Lowland & M-L & $\mathrm{L}$ & M & M & $\mathrm{L}$ & M & $\mathrm{L}$ & M & $\mathrm{L}$ & $\mathrm{M}$ & $\mathrm{L}$ \\
\hline Brosot & Lowland & M-L & $\mathrm{L}$ & $\mathrm{L}$ & M & $\mathrm{L}$ & $\mathrm{L}$ & $\mathrm{L}$ & $\mathrm{L}$ & $\mathrm{L}$ & M & $\mathrm{L}$ \\
\hline Pandowan & Lowland & L-L & $\mathrm{L}$ & M & $\mathrm{L}$ & $\mathrm{L}$ & $\mathrm{L}$ & $\mathrm{L}$ & $\mathrm{L}$ & $\mathrm{L}$ & $\mathrm{L}$ & $\mathrm{L}$ \\
\hline Tirtorahayu & Lowland & M-L & $\mathrm{L}$ & $\mathrm{L}$ & M & $\mathrm{L}$ & M & $\mathrm{L}$ & M & M & M & $\mathrm{L}$ \\
\hline Wahyuharjo & Lowland & L-L & N/A & N/A & N/A & N/A & N/A & N/A & N/A & N/A & N/A & N/A \\
\hline Bumirejo & Lowland & L-L & $\mathrm{L}$ & $\mathrm{L}$ & $\mathrm{L}$ & $\mathrm{L}$ & $\mathrm{L}$ & $\mathrm{L}$ & $\mathrm{L}$ & M & $\mathrm{L}$ & M \\
\hline Jatirejo & Lowland & L-L & $\mathrm{L}$ & $\mathrm{L}$ & M & M & $\mathrm{L}$ & $\mathrm{L}$ & N/A & $\mathrm{L}$ & $\mathrm{L}$ & $\mathrm{L}$ \\
\hline Sidorejo & Lowland & H-L & $\mathrm{H}$ & $\mathrm{L}$ & $\mathrm{L}$ & $\mathrm{H}$ & M & $\mathrm{H}$ & $\mathrm{H}$ & $\mathrm{H}$ & M & M \\
\hline Gulurejo & Lowland & M-L & M & $\mathrm{L}$ & $\mathrm{L}$ & $\mathrm{H}$ & M & $\mathrm{H}$ & $\mathrm{L}$ & $\mathrm{H}$ & $\mathrm{H}$ & $\mathrm{L}$ \\
\hline Ngentakrejo & Lowland & H-L & $\mathrm{L}$ & $\mathrm{L}$ & $\mathrm{L}$ & $\mathrm{L}$ & $\mathrm{L}$ & $\mathrm{L}$ & $\mathrm{L}$ & $\mathrm{L}$ & $\mathrm{L}$ & $\mathrm{L}$ \\
\hline Demangrejo & Transitional & L-L & N/A & N/A & N/A & N/A & N/A & N/A & N/A & N/A & N/A & N/A \\
\hline Srikayangan & Transitional & M-L & $\mathrm{L}$ & $\mathrm{L}$ & $\mathrm{L}$ & $\mathrm{L}$ & $\mathrm{L}$ & $\mathrm{L}$ & $\mathrm{L}$ & $\mathrm{L}$ & $\mathrm{L}$ & $\mathrm{L}$ \\
\hline Tuksono & Transitional & $\mathrm{M}-\mathrm{H}$ & $\mathrm{L}$ & $\mathrm{L}$ & $\mathrm{L}$ & $\mathrm{L}$ & $\mathrm{L}$ & $\mathrm{L}$ & $\mathrm{L}$ & $\mathrm{L}$ & $\mathrm{L}$ & $\mathrm{L}$ \\
\hline Salamrejo & Transitional & L-L & $\mathrm{L}$ & $\mathrm{L}$ & $\mathrm{L}$ & $\mathrm{L}$ & $\mathrm{L}$ & $\mathrm{L}$ & $\mathrm{L}$ & $\mathrm{L}$ & $\mathrm{L}$ & $\mathrm{L}$ \\
\hline Sukoreno & Transitional & L-L & N/A & N/A & N/A & N/A & N/A & N/A & N/A & N/A & N/A & N/A \\
\hline Kaliagung & Transitional & M-L & $\mathrm{L}$ & $\mathrm{L}$ & $\mathrm{L}$ & $\mathrm{L}$ & $\mathrm{L}$ & $\mathrm{L}$ & $\mathrm{L}$ & $\mathrm{L}$ & $\mathrm{L}$ & $\mathrm{L}$ \\
\hline Sentolo & Transitional & $\mathrm{H}-\mathrm{L}$ & N/A & N/A & N/A & N/A & N/A & N/A & N/A & N/A & N/A & N/A \\
\hline Banguncipto & Transitional & M-L & $\mathrm{L}$ & $\mathrm{L}$ & $\mathrm{L}$ & $\mathrm{L}$ & $\mathrm{L}$ & $\mathrm{L}$ & $\mathrm{L}$ & $\mathrm{L}$ & $\mathrm{L}$ & $\mathrm{L}$ \\
\hline Tawangsari & Transitional & L-L & N/A & $\mathrm{N} / \mathrm{A}$ & N/A & N/A & $\mathrm{N} / \mathrm{A}$ & N/A & N/A & N/A & $\mathrm{N} / \mathrm{A}$ & N/A \\
\hline Karangsari & Transitional & $\mathrm{H}-\mathrm{L}$ & $\mathrm{L}$ & $\mathrm{L}$ & $\mathrm{L}$ & $\mathrm{L}$ & $\mathrm{L}$ & $\mathrm{L}$ & $\mathrm{L}$ & L & $\mathrm{L}$ & $\mathrm{L}$ \\
\hline
\end{tabular}




\begin{tabular}{|c|c|c|c|c|c|c|c|c|c|c|c|c|}
\hline Village & $\begin{array}{c}\text { Geographical } \\
\text { Zone }\end{array}$ & Type & (1) & $(2)$ & (3) & (4) & (5) & (6) & (7) & (8) & (9) & (10) \\
\hline Kedungsari & Transitional & M-L & $\mathrm{L}$ & $\mathrm{L}$ & $\mathrm{L}$ & $\mathrm{L}$ & $\mathrm{L}$ & $\mathrm{L}$ & $\mathrm{L}$ & $\mathrm{L}$ & $\mathrm{L}$ & $\mathrm{L}$ \\
\hline Margosari & Transitional & M-L & $\mathrm{L}$ & $\mathrm{L}$ & $\mathrm{L}$ & $\mathrm{L}$ & $\mathrm{L}$ & $\mathrm{L}$ & $\mathrm{L}$ & $\mathrm{L}$ & $\mathrm{L}$ & $\mathrm{L}$ \\
\hline Pengasih & Transitional & H-M & N/A & N/A & N/A & N/A & N/A & N/A & N/A & $\mathrm{N} / \mathrm{A}$ & N/A & N/A \\
\hline Sendangsari & Transitional & $\mathrm{L}-\mathrm{L}$ & $\mathrm{L}$ & $\mathrm{L}$ & $\mathrm{L}$ & $\mathrm{L}$ & $\mathrm{L}$ & $\mathrm{L}$ & $\mathrm{L}$ & $\mathrm{L}$ & $\mathrm{L}$ & $\mathrm{L}$ \\
\hline Sidomulyo & Transitional & M-L & $\mathrm{L}$ & $\mathrm{L}$ & $\mathrm{L}$ & $\mathrm{L}$ & $\mathrm{L}$ & $\mathrm{L}$ & $\mathrm{L}$ & $\mathrm{L}$ & $\mathrm{L}$ & $\mathrm{L}$ \\
\hline Hargomulyo & Transitional & M-L & $\mathrm{H}$ & $\mathrm{L}$ & M & M & M & $\mathrm{L}$ & $\mathrm{L}$ & M & $\mathrm{L}$ & $\mathrm{L}$ \\
\hline Hargorejo & Transitional & $\mathrm{L}-\mathrm{L}$ & $\mathrm{L}$ & $\mathrm{L}$ & M & M & M & $\mathrm{L}$ & $\mathrm{L}$ & M & $\mathrm{L}$ & $\mathrm{L}$ \\
\hline Hargowilis & Transitional & M-H & $\mathrm{H}$ & $\mathrm{L}$ & M & $\mathrm{L}$ & M & $\mathrm{L}$ & $\mathrm{L}$ & M & $\mathrm{L}$ & $\mathrm{L}$ \\
\hline Kalirejo & Transitional & M-M & M & $\mathrm{L}$ & M & $\mathrm{L}$ & $\mathrm{L}$ & $\mathrm{L}$ & $\mathrm{L}$ & M & $\mathrm{L}$ & $\mathrm{L}$ \\
\hline Hargotirto & Transitional & M-H & M & $\mathrm{L}$ & M & $\mathrm{L}$ & $\mathrm{L}$ & $\mathrm{L}$ & $\mathrm{L}$ & $\mathrm{L}$ & $\mathrm{L}$ & $\mathrm{L}$ \\
\hline Jatimulyo & Transitional & H-L & $\mathrm{L}$ & $\mathrm{L}$ & M & $\mathrm{L}$ & $\mathrm{L}$ & $\mathrm{L}$ & $\mathrm{L}$ & M & M & $\mathrm{L}$ \\
\hline Giripurwo & Transitional & $\mathrm{H}-\mathrm{H}$ & $\mathrm{L}$ & N/A & $\mathrm{L}$ & $\mathrm{L}$ & $\mathrm{L}$ & $\mathrm{L}$ & $\mathrm{L}$ & $\mathrm{L}$ & $\mathrm{L}$ & $\mathrm{L}$ \\
\hline Pendoworejo & Upland & M-L & $\mathrm{L}$ & $\mathrm{H}$ & $\mathrm{H}$ & M & $\mathrm{H}$ & M & $\mathrm{L}$ & M & M & $\mathrm{L}$ \\
\hline Purwosari & Upland & M-L & M & M & $\mathrm{H}$ & $\mathrm{L}$ & $\mathrm{H}$ & M & $\mathrm{L}$ & $\mathrm{H}$ & M & M \\
\hline Banyuroto & Upland & M-L & $\mathrm{L}$ & $\mathrm{L}$ & $\mathrm{L}$ & $\mathrm{L}$ & $\mathrm{L}$ & $\mathrm{L}$ & $\mathrm{L}$ & $\mathrm{L}$ & $\mathrm{L}$ & $\mathrm{L}$ \\
\hline Donomulyo & Upland & H-L & $\mathrm{L}$ & $\mathrm{L}$ & $\mathrm{L}$ & $\mathrm{L}$ & $\mathrm{L}$ & $\mathrm{L}$ & $\mathrm{L}$ & $\mathrm{L}$ & $\mathrm{L}$ & $\mathrm{L}$ \\
\hline Wijimulyo & Upland & $\mathrm{L}-\mathrm{L}$ & $\mathrm{L}$ & $\mathrm{L}$ & $\mathrm{L}$ & $\mathrm{L}$ & $\mathrm{L}$ & $\mathrm{L}$ & $\mathrm{L}$ & $\mathrm{L}$ & $\mathrm{L}$ & $\mathrm{L}$ \\
\hline Tanjungharjo & Upland & M-L & $\mathrm{L}$ & $\mathrm{L}$ & $\mathrm{L}$ & $\mathrm{L}$ & $\mathrm{L}$ & $\mathrm{L}$ & $\mathrm{L}$ & $\mathrm{L}$ & $\mathrm{L}$ & $\mathrm{L}$ \\
\hline Jatisarono & Upland & $\mathrm{L}-\mathrm{L}$ & N/A & $\mathrm{N} / \mathrm{A}$ & N/A & N/A & N/A & N/A & N/A & N/A & N/A & N/A \\
\hline Kembang & Upland & $\mathrm{L}-\mathrm{L}$ & $\mathrm{L}$ & $\mathrm{L}$ & $\mathrm{L}$ & $\mathrm{L}$ & $\mathrm{L}$ & $\mathrm{L}$ & $\mathrm{L}$ & $\mathrm{L}$ & $\mathrm{L}$ & $\mathrm{L}$ \\
\hline Banjararum & Upland & M-L & $\mathrm{L}$ & $\mathrm{L}$ & $\mathrm{L}$ & $\mathrm{L}$ & $\mathrm{L}$ & $\mathrm{L}$ & $\mathrm{L}$ & $\mathrm{L}$ & $\mathrm{L}$ & $\mathrm{L}$ \\
\hline Banjarasri & Upland & $\mathrm{L}-\mathrm{L}$ & $\mathrm{L}$ & $\mathrm{L}$ & $\mathrm{L}$ & $\mathrm{L}$ & $\mathrm{L}$ & $\mathrm{L}$ & $\mathrm{L}$ & $\mathrm{L}$ & $\mathrm{L}$ & $\mathrm{L}$ \\
\hline Banjarharjo & Upland & H-L & $\mathrm{L}$ & $\mathrm{L}$ & $\mathrm{L}$ & $\mathrm{L}$ & $\mathrm{L}$ & $\mathrm{L}$ & $\mathrm{L}$ & $\mathrm{L}$ & $\mathrm{L}$ & $\mathrm{L}$ \\
\hline Banjaroya & Upland & M-L & $\mathrm{L}$ & $\mathrm{L}$ & $\mathrm{L}$ & $\mathrm{L}$ & $\mathrm{L}$ & $\mathrm{L}$ & $\mathrm{L}$ & $\mathrm{L}$ & $\mathrm{L}$ & $\mathrm{L}$ \\
\hline Kebonharjo & Upland & $\mathrm{H}-\mathrm{L}$ & $\mathrm{L}$ & $\mathrm{N} / \mathrm{A}$ & N/A & N/A & N/A & N/A & N/A & N/A & N/A & N/A \\
\hline Banjarsari & Upland & M-L & $\mathrm{L}$ & $\mathrm{L}$ & $\mathrm{L}$ & N/A & N/A & N/A & $\mathrm{L}$ & N/A & N/A & N/A \\
\hline Purwoharjo & Upland & $\mathrm{H}-\mathrm{H}$ & $\mathrm{L}$ & $\mathrm{L}$ & $\mathrm{L}$ & $\mathrm{L}$ & $\mathrm{L}$ & $\mathrm{L}$ & $\mathrm{L}$ & $\mathrm{N} / \mathrm{A}$ & $\mathrm{L}$ & $\mathrm{N} / \mathrm{A}$ \\
\hline Sidoharjo & Upland & L-H & $\mathrm{L}$ & $\mathrm{L}$ & M & M & M & $\mathrm{L}$ & M & $\mathrm{L}$ & M & $\mathrm{L}$ \\
\hline Gerbosari & Upland & M-L & $\mathrm{L}$ & $\mathrm{L}$ & M & $\mathrm{L}$ & M & $\mathrm{L}$ & M & M & $\mathrm{L}$ & $\mathrm{L}$ \\
\hline Ngargosari & Upland & M-H & $\mathrm{L}$ & $\mathrm{L}$ & N/A & N/A & N/A & N/A & N/A & N/A & N/A & N/A \\
\hline Pagerharjo & Upland & L-M & $\mathrm{L}$ & $\mathrm{L}$ & $\mathrm{L}$ & $\mathrm{L}$ & $\mathrm{L}$ & $\mathrm{L}$ & $\mathrm{L}$ & $\mathrm{L}$ & $\mathrm{H}$ & $\mathrm{H}$ \\
\hline
\end{tabular}

1. Sign of the colour show the class difference among local food production, darker color shows higher class. Meanwhile, N/A = No Data, $\mathrm{L}=$ Low, $\mathrm{M}=$ Medium, $\mathrm{H}=\mathrm{High}$. This visualisation adopt the idea of heat map result (Toddenroth, et al., 2014), but I tabulate manually for the presentation

2. The name of local food crops: (1) cassava/ubi kayu; (2) sweet potato/ubi jalar; (3) edible canna/ ganyong; (4) arrowroot/garut; (5) prasina/gadung; (6) birch rim yam/gembili; (7) pumpkin/ labu kuning; (8) tuber/uwi; (9) bread fruit/ sukun; (10) elephant's foot/suweg. 